\title{
Cardio-protective Effect of Vitamin E on Doxorubicin-Induced Cardiotoxicity in Adult Male Albino Rats: A Histological and Biochemical Study
}

\author{
Original \\ Amal Rateb Abdel-Samia ${ }^{1 \& 2}$, Reneah R. Bushra', Asmaa M.S. Gomaa ${ }^{3}$ \\ Article \\ ${ }^{1}$ Department of Human Anatomy and Embryology, Faculty of Medicine, Assiut University, \\ ${ }^{2}$ Department of Basic Sciences, King Saud Bin AbdulAziz University for health Sciences- Al \\ Hasa, Saudia Arabia \\ ${ }^{3}$ Medical Physiology Department, Faculty of Medicine, Assiut University
}

\begin{abstract}
Background: Doxorubicin (Dox) is a powerful and greatly effective drug in cancer. However, its clinical usefulness is still restricted due to its specific toxicity to the cardiac tissue. Vitamin E is a well-known antioxidant used as a dietary supplement. Aim of the work: To evaluate the possible protective effects of vitamin E against Dox-induced cardiotoxicity.

Material and Methods: Forty 3-months adult male albino rats weighing 200-250 gm were divided into four equal groups: Group (I): served as a negative control and received no treatment. Group (II): served as a positive control and treated with an intraperitoneal injection of $0.9 \%$ sodium chloride saline once daily for one week. Group (III): treated with $4 \mathrm{mg}$ Dox $/ \mathrm{kg}$ b.w./ day intraperitoneally for one week. Group (IV): was pretreated with $100 \mathrm{mg}$ vitamin E/kg body weight/day orally for 2 weeks followed by a combination of an intraperitoneal injection of Dox and oral vitamin $\mathrm{E}$ for one week in the same previous doses. Then, the animals were anaesthetized and blood samples were utilized for measurement of lactate dehydrogenase (LDH), creatine kinase (CK), triglyceride, total cholesterol and high-density lipoprotein (HDL-C). Animals were sacrificed, and a portion of each heart was taken from all groups for determination of the levels of total cardiac antioxidant capacity (TAC). The remaining portions of the heart muscle were prepared for light and electron microscopic studies.

Results: Administration of Dox resulted in histological alterations in the form of vacuolated disorganized cardiac muscle fibers, degenerated mitochondria and congested dilated blood vessels. Also, significant decreases of cardiac TAC and serum HDL-C and increases of serum levels of LDH, CK, triglyceride and total cholesterol of Dox-treated group were noticed in comparison with the control ones. Pre and concomitant administration of vitamin E with Dox improved these alterations.

Conclusion: Vitamin E ameliorates the cardiac damage induced by Dox.
\end{abstract}

Received: 12 September 2018, Accepted: 21 November 2018

Key Words: Cardiac muscle, doxorubicin, rat, vitamin E,

Corresponding Author: Reneah Refaat Bushra, MD, Department of Human Anatomy and Embryology, Faculty of Medicine, Assiut University, Egypt, Tel.: +20 1207949154, E-mail: yosteena.atef2000@gmail.com

ISSN: $1110-0559$, Vol. 42, No. 1

\section{INTRODUCTION}

One of the major public health problems is cancer. More than six million patients die every year because of that disease ${ }^{[1]}$. Doxorubicin (Dox) is one of the widely used chemotherapeutic drugs for treatment of leukemia, esophageal, lung and breast carcinomas due to its proved great efficacy. It comes under the anthracycline group of antibiotics. It is derived from the algae, Streptomyces peucetius var. caesius ${ }^{[2,3]}$. However, due to drawbacks on the healthy tissues, its use is restricted. Many authors proved that, an accumulative Dox administration could lead to cardiomyopathy and congestive heart failure ${ }^{[4]}$.
Cardiac muscle tissue or myocardium forms the bulk of the heart. The heart wall is a three layered structure with a thick layer of myocardium sandwiched between an inner endocardium and an outer epicardium ${ }^{[5]}$.

Dox-induced cardiotoxicity might be attributed to lipid peroxidation, mitochondrial destruction ${ }^{[6]}$, increased oxidative stress and decreased endogenous antioxidant deficits $^{[7]}$.

Vitamin E is a well-known antioxidant and free radical scavenger agent ${ }^{[8]}$. So, this study was initiated aiming to test the hypothesis whether vitamin $\mathrm{E}$ has a protective effect on cardiotoxicity in rats receiving doxorubicin or not. 


\section{MATERIAL AND METHODS}

\section{Chemicals}

Doxorubicin/Adricin was obtained in red-colored, transparent solution in a colorless vial (EIMC United Pharmaceuticals Company, 10mg Doxorubicin hydrochloride/ vial, CAS number: $23214-92-8$ ) dissolved in $0.9 \%$ sodium chloride saline. Vitamin $\mathrm{E}$ was purchased in the form of capsules of yellow oily material (tocopherol, $\alpha$ 1000mg/ capsule, Pharco Pharmaceutical company, Egypt).

\section{Selection of animals}

The current study was performed at the Faculty of Medicine, Assiut University dated from 2017 to 2018. A total number of forty 3-months adult male albino rats were utilized in this study with an average weight 200-250gm each. Animals were obtained from the Animal House of Assiut University and they were kept under standard laboratory conditions with a free access to the food and the water. Ethical clearance for the use of animals was got from the Institutional Animal Ethics Committee prior to the beginning of the work.

\section{Experimental design}

The animals were randomly categorized into 4 groups of 10 animals each as follows:

\section{Group I (negative control group):}

The rats received no treatment.

\section{Group II (positive control group):}

Animals were treated daily with once intraperitoneal injection of $0.9 \%$ sodium chloride saline solution for one week.

\section{Group III (Dox-treated group):}

Animals were treated with a dose of $4 \mathrm{mg} / \mathrm{kg}$ body weight/day through intraperitoneal injection for one week. The dose was adopted according to the therapeutically equivalent one ${ }^{[9]}$.

\section{Group IV (Dox+Vitamin E group):}

Rats were treated with $100 \mathrm{mg}$ Vitamin $\mathrm{E} / \mathrm{kg}$ body weight/day orally for 2 weeks followed by $4 \mathrm{mg}$ Dox $/ \mathrm{kg}$ body weight/ day (through intraperitoneal injection) in conjunction with $100 \mathrm{mg}$ Vitamin $\mathrm{E} / \mathrm{kg}$ body weight/day orally for further one week ${ }^{[9]}$.

\section{Biochemical study:}

Then, for estimation of cardiac biomarkers: lactate dehydrogenase (LDH) and creatine-kinase (CK), and lipid profile: triglyceride, total cholesterol and high-density lipoprotein (HDL-C), orbital blood samples were collected from all animal groups under light ether anesthesia using heparinized microcapillaries. Then, they were centrifuged at 3000 round per minute $(\mathrm{rpm})$ for $15 \mathrm{~min}$. The clear supernatant sera were removed and kept at $-20{ }^{\circ} \mathrm{C}$ until using the commercially available kits (Chema Diagnostica,
Egypt) according to the manufacturer's instructions. Then, all animals were sacrificed under ether anesthesia and a midline abdominal incision was made and heart tissues were quickly dissected out, washed with ice-cold saline and immediately dried on a filter paper and a portion of each group was kept at $-80^{\circ} \mathrm{C}$, homogenized in phosphate buffer and the homogenate was centrifuged for $15 \mathrm{~min}$ at $4^{\circ} \mathrm{C}$ to measure the total antioxidant capacity (TAC) using the commercially available kit (Bio-Diagnostics, Egypt) ${ }^{[10]}$.

\section{Histological study:}

The remaining portions of the heart tissue were taken from all groups and prepared for light and electron histological microscopic study.

Preparation of paraffin sections: small pieces of the heart myocardium (left ventricle) were fixed by immersion in formal saline solution $10 \%$ for 3 days. The specimens were dehydrated in ascending grades of ethyl alcohol (70\%-90\%-100\%) and cleared in xylene. The specimens were impregnated for three changed in paraffin and were finally embedded in paraffin wax. The paraffin blocks were cut by rotary microtome into serial transverse sections at $5 \mu$-thick and stained with haematoxylin and eosin stain for the study of the general structures. Special stains as Masson's Trichrome, PAS and Van Gieson were also used to examine the cardiac tissue ${ }^{[11]}$.

Preparation of transmission electron microscopic sections: tissues of the left ventricles were trimmed to very small pieces $(1 \mathrm{~mm} 3)$. They were fixed into $2.5 \%$ glutaraldhyde in $100 \mathrm{mmol} / 1$ sodium cacodylate buffer (pH 7.4) for 6 hours. After washing in cacodylate buffer, the tissue was post-fixed in $1 \% \mathrm{CsO} 4$ buffered with 100 $\mathrm{mmol} / 1$ sodium cacodylate for two hours, raised with buffer for thirty minutes and dehydrated with ascending grades of ethanols (30-100\% thirty minutes each). Samples were infiltrated with 1:1 mixtures of $100 \%$ ethanol and epoxy resin for four hours, followed by three changes 2 hours each and one change 8 hours infiltration steps in 100\% resin. Samples were placed uniquely labeled models with $100 \%$ resin and polymerized in a $65 \mathrm{oC}$ oven overnight. Sections of tissue approximately $1 \mu$-thick were cut, stained with $1 \%$ aqueous Toluidine blue and examined by light microscopy. Subsequently, ultrathin sections $(0.1 \mu \mathrm{m})$ thickness were cut and stained with uranyl acetate and lead citrate $^{[13]}$, examined using "Jeol-JEM-100 CX II" electron microscope and photographed at the Electron Microscopic Unit of Assiut University.

\section{Statistical analysis}

The biochemical results were expressed as means $\pm \mathrm{SD}$. Multiple comparisons testing were done using ANOVA. A value of $\mathrm{p} \leq 0.05$ was considered statistically significant. All analyses were carried out with SPSS version 16.0 (SPSS Inc., Chicago, USA).

\section{RESULTS}

\section{Biochemical Results:}


Serum levels of triglyceride and total cholesterol were significantly increased, while HDL-C serum level was significantly decreased in the Dox-treated group in comparison with the control groups. Decreased serum levels of triglyceride and total cholesterol and an increase of the HDL-C in the Dox+Vitamin E group were noticed when compared with the Dox-treated group. Dox+Vitamin E group showed insignificant differences in the triglyceride, total cholesterol, and HDL levels when compared with the control groups (Table 1) (Histogram 1).

A significant increase of both LDH and CK levels of the Dox-treated group in comparison with the control groups was noticed. Dox+Vitamin E treatment resulted in a significant decrease of the LDH and CK level when compared with the Dox-treated group. Dox+Vitamin E group showed insignificant differences of the LDH level when compared with the control groups while the CK level showed a significant increase when compared with the control groups (Table 1) (Histogram 2).

There was an insignificant difference in the biochemical results between the negative and positive control groups. There was a significant decrease in the cardiac TAC level of the Dox-treated group in comparison with the control groups. Dox+Vitamin E treatment resulted in a significant increase in the cardiac TAC level when compared with the Dox-treated group. An insignificant difference in the cardiac TAC level between the control and Dox+Vitamin E groups was found (Table 1) (Histogram 2).

\section{II- Histological results:}

- Groups I and II (negative and positive control groups):

The sections of the left ventricular wall stained with haematoxylin and eosin of the positive control group showed a histological architecture as normal as that of the negative control one.

\section{Light microscopic results:}

The control groups' sections exhibited branching and anastomosing cardiac muscle fibers running in various directions accompanied by acidophilic sarcoplasm. The fibers appeared regularly arranged with regular transverse and longitudinal striations. The cardiomyocytes presented oval central vesicular nuclei (Figs.1,2). Semithin sections stained with Toluidine blue further clarified that the cardiac muscle fibers exhibited distinct cross striations banding pattern. The adjacent cardiac muscle cells revealed prominent intercalated discs that crossed the chain of the cardiac cells and represented specialized end-to-end junctions (Fig.3). Sections stained by Masson's trichrome revealed scanty green stained connective tissue surrounding the muscle fibers (Fig.4). Furthermore sections stained with PAS showed a positive reaction (Fig.5) and sections stained with Van Gieson revealed very scanty amount of collagen fibers between the cardiac muscle fibers (Fig.6).

\section{Electron microscopic results:}

Ultrathin sections of the left ventricular wall of the control groups revealed regularly arranged myofibrils in the form of parallel rays, varying in diameter and exhibiting alternating thick dark (A) and light (I) bands with regularly $\mathrm{Z}$ lines in the middle of I bands. Numerous mitochondria displaying closely packed cristae were seen in rows between the myofibrils. The nuclear chromatin appeared evenly dispersed inside the nucleus and the nuclear membrane was well defined. The cardiac muscle fibers were found to be formed of myocytes attached end-toend by intercalated disks. Each intercalated disc consisted of a stepwise arrangement of transverse and longitudinal components (Figs. 7-9).

- Group III (Dox-treated group):

\section{Light microscopic results:}

Haematoxylin and eosin stained-sections of the left ventricular wall revealed disorganized, widely separated fragmented cardiac muscle fibers with deeply stained pyknotic nucleus. Extensive vacuolations were also observed between the muscle fibers (Figs.10,11). Semithin sections stained with Toluidine blue revealed severe disruption of architectures of the myofibrils with fragmented cardiac muscle fibers. The nuclei appeared with variable abnormal shaped and dilated blood vessels. There was also several areas of loss of myofibrils (Figs.12-14). Masson Trichrome stained sections showed noticeable increase in collagen fibers of the surrounding endomysium of the cardiac myocytes (Fig.15). Sections stained with PAS showed strong positive reaction (Fig.16). Van Gieson stained sections revealed noticeable increase in the amount of collagen fibers between cardiac muscle fibers (Fig.17)

\section{Electronic microscopic results:}

Ultrathin sections of the left ventricular wall showed disorganization, fragmentation and wide separation of the myofibrils. Also, there were irregularly arranged degenerated mitochondria with rupture of its membrane, disruption and/or loss of cristea and swelling. The nuclei showed either shrunken with irregular, corrugated or rupture membrane with chromatin margination. Altered intermyocyte junctions and degradation of myofilaments were seen. $Z$ lines appeared obscured in most regions. Focal preservation of the $\mathrm{Z}$ lines and extensive vacouolations were also seen (Figs.18-23).

\section{- Group IV (Dox + Vitamin E group): \\ Light microscopic results:}

Left ventricular wall sections stained with haematoxylin and eosin showed nearly normal architecture of cardiac muscle fibers. Cardiomyocytes revealed many vesicular nuclei (Fig.24). Semithin section stained with Toluidine blue revealed nearly normal appearance of cardiac muscle 
fibers with vesicular nuclei. Focal area of the disruption of the striated appearance of the myofibrils and scanty vacuolations between the cardiomyocytes were also observed (Fig.25). Masson's Trichrome manifested general appearance nearly similar to the control group (Fig.26). Sections stained with PAS positive reaction appeared nearly as the control group (Fig.27). Van Gieson stain revealed very minimal amount of collagen fibers as the control group (Fig.28).

\section{Electron microscopic results:}

Ultrastructural examination for sections of the wall of left ventricle showed regular arrangement of the myofibrils with alternating dark and light bands. Few areas of disorganized fibrils were observed. Most of the myofilaments were regularly arranged in sarcomeres between $\mathrm{Z}$ lines while few showed vacuolations. Between the myofibrils numerous mitochondria lay exhibiting regular cristae while some appeared swollen and condensed. The nuclear chromatin appeared evenly dispersed inside the nucleus and the nuclear membrane was well defined in most of the myocytes while very few ones showed irregular corrugated nuclear outline (Figs.29-31).

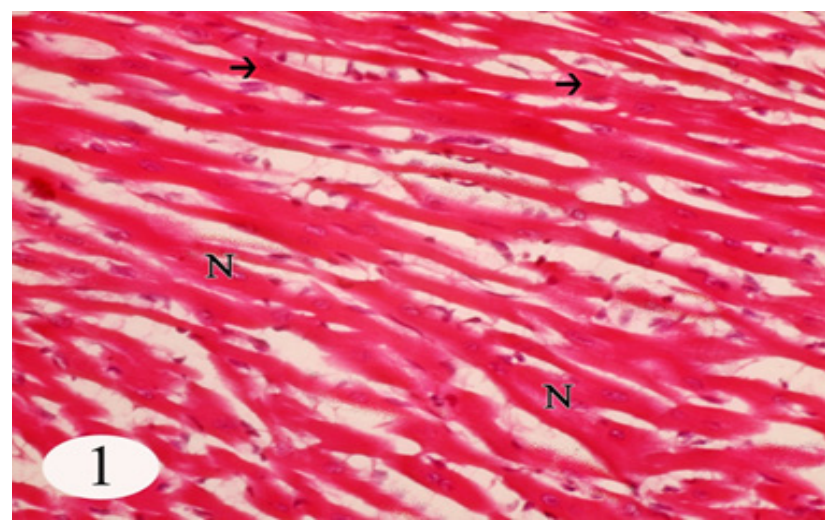

Fig. 1: A photomicrograph of longitudinal section in the left ventricular wall of a control rat showing the myocardium with its usual appearance of branching and anastomosing cardiac muscle fibers running in various directions with acidophilic sarcoplasm (arrow). Cardiomyocytes have central vesicular nuclei $(\mathrm{N})$.

Hx. \& E.; X1000

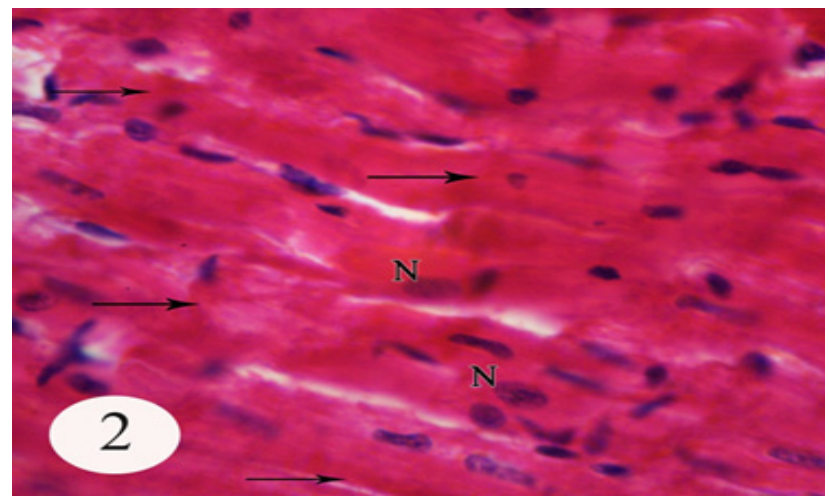

Fig. 2: A photomicrograph of longitudinal section in the left ventricular wall of a control rat showing cardiomyocytes (arrow) with central vesicular nuclei $(\mathrm{N})$.

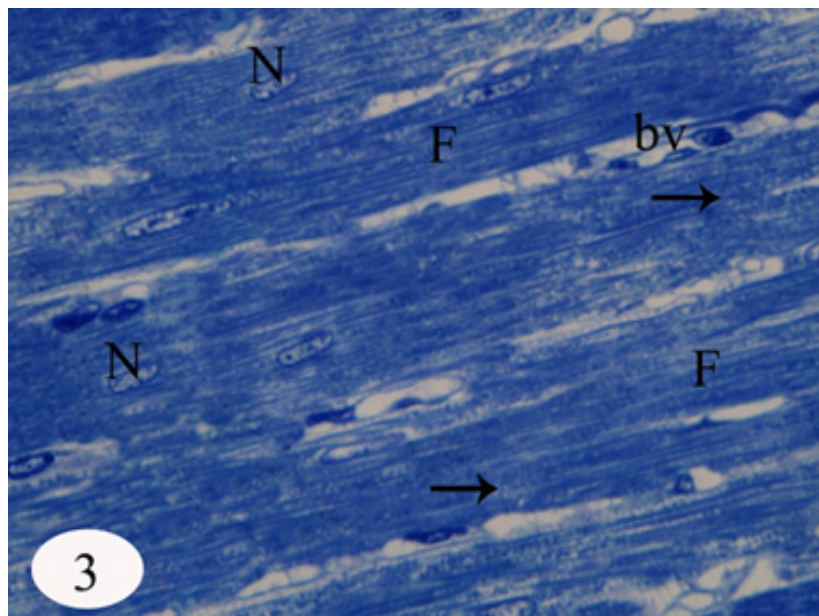

Fig. 3: A photomicrograph of a semithin section in the left ventricular wall of a control rat exhibiting the myocardium with the standard architecture of branching and anastomosing cardiac muscle fibers running in different directions (F). Cardiomyocytes have oval euchromatic central vesicular nuclei $(\mathrm{N})$. Notice the blood vessels (bv) in between the muscle fibers. Note the intercalated disc (arrows). Toluidine blue; X1000

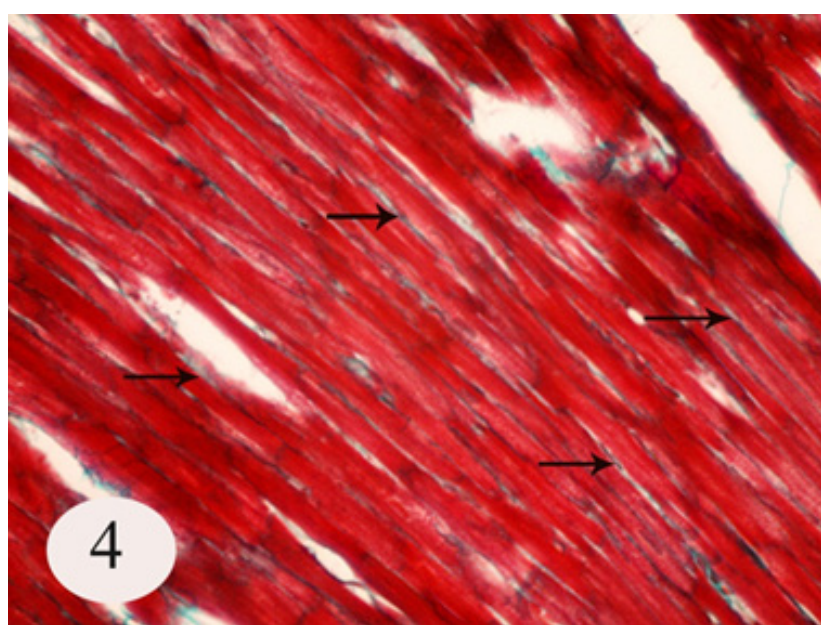

Fig. 4: A photomicrograph of a longitudinal section in the left ventricular wall of a control rat showing scanty collagen fibers between the cardiac myocytes (arrows).

Masson's Trichrome X 1000

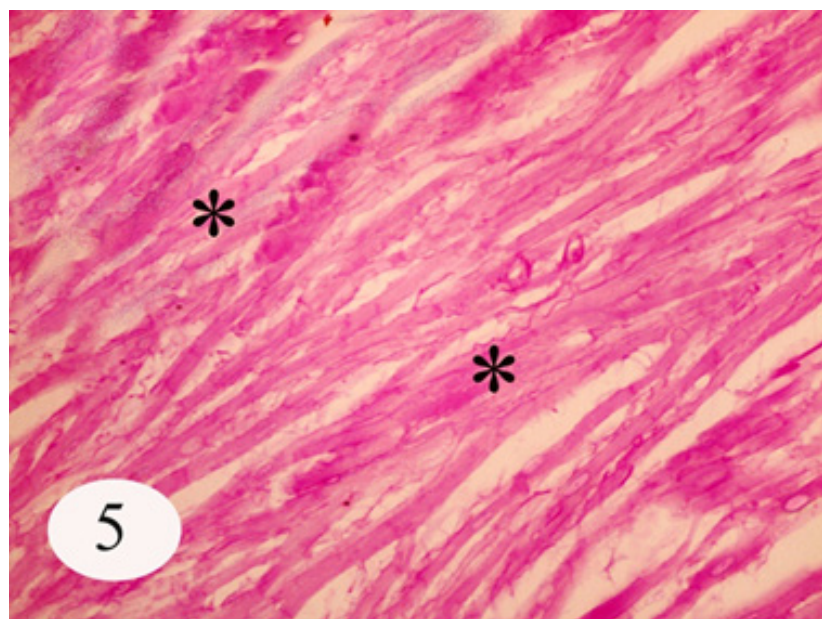

Fig. 5: A photomicrograph of a longitudinal section in the left ventricula wall of a control rat showing cardiomyocytic positive PAS reaction $\left(^{*}\right)$.

PAS $\times 1000$ 


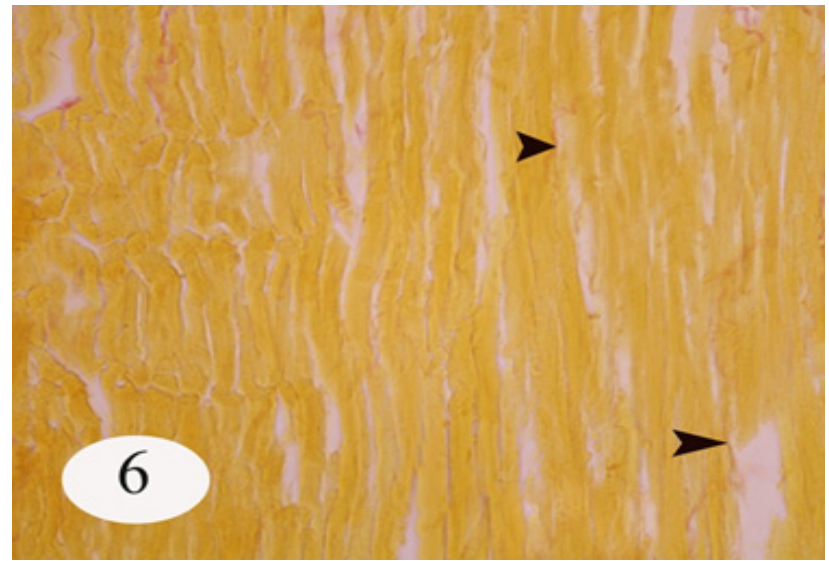

Fig. 6: A Photomicrograph of a longitudinal section of the left ventricular wall of a control rat showing very scanty amount of collagen fibers (arrowheads) between the cardiac muscle fibers. Van Gieson x 1000

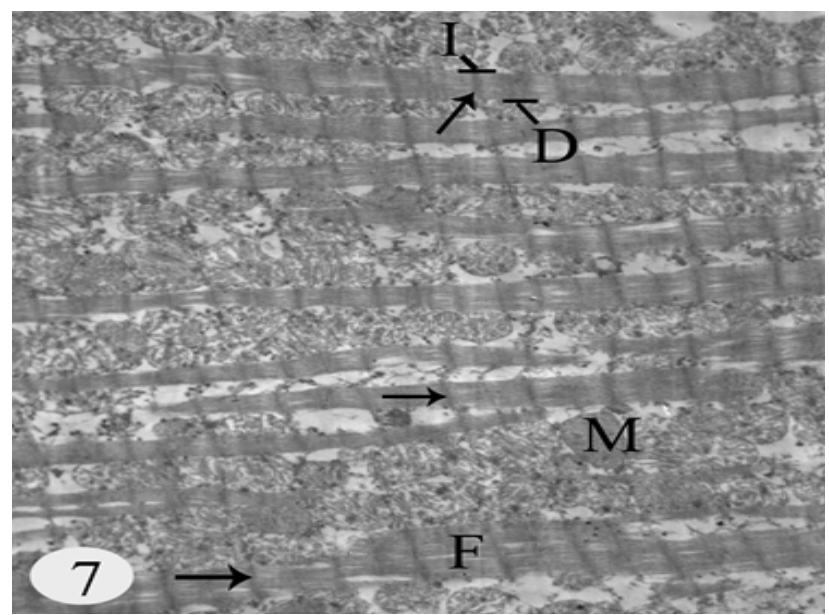

Fig. 7: An electron micrograph of the left ventricular wall of a control rat showing parallel rays of regular arranged myofibrils (F) revealing alternating dark (D) and light bands (I), regular Z lines (arrow) and numerous mitochondria (M) arranged in a row in between the myofibrils. X 5800

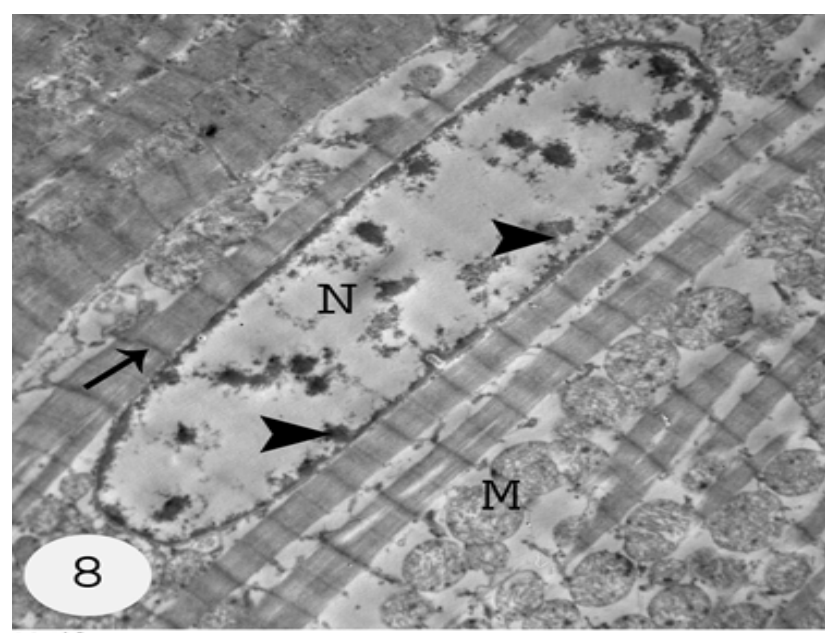

Fig. 8: An electron micrograph of the left ventricular wall of a control rat revealing usual histological structure of the myofibrils with regular $\mathrm{Z}$ lines (arrow) appear in the middle of $\mathrm{I}$ bands with an oval rod shaped euchromatic nucleus $(\mathrm{N})$ with patches of heterochromatin (arrowhead). Notice rows of mitochondria (M).

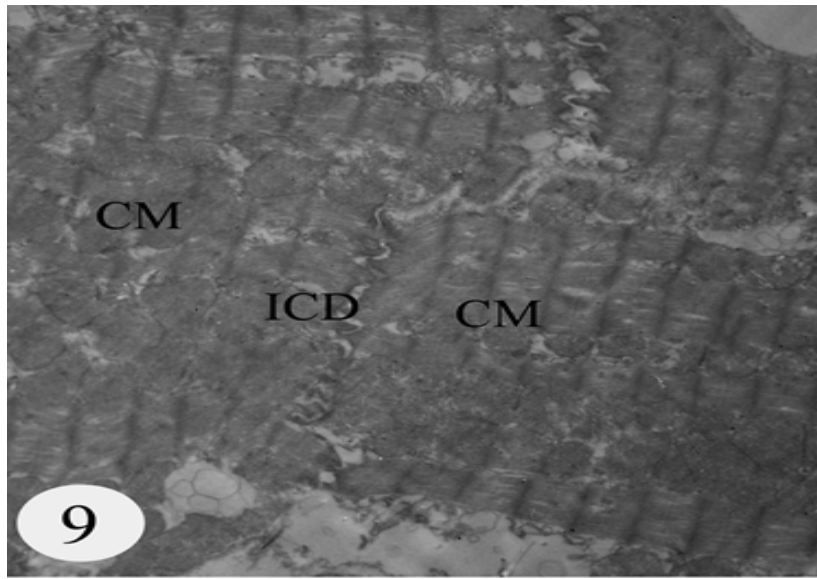

Fig. 9: An electron micrograph of the left ventricular wall of a control rat showing step-like intercalated disc (ICD) crossing the myofibrils and joining the two adjacent cardiac myocytes (CM)

X 5800

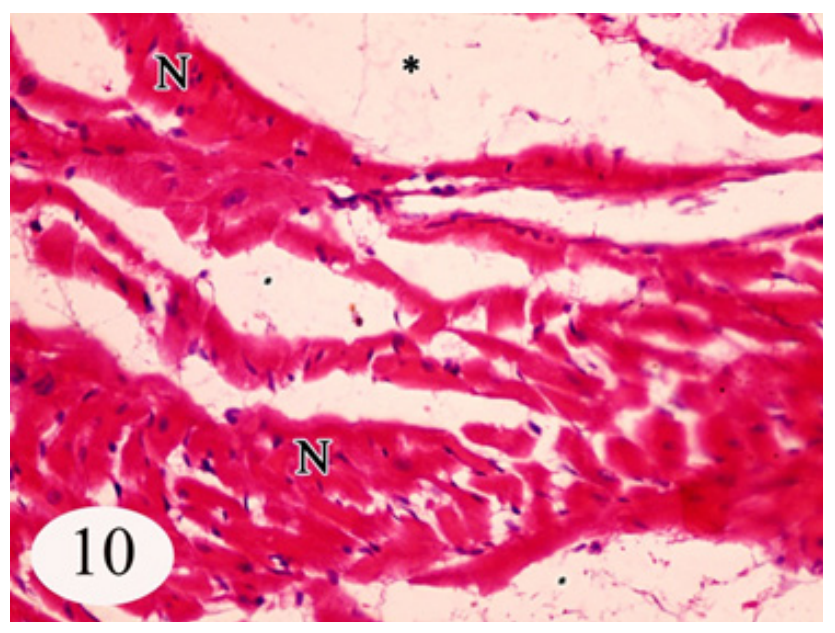

Fig.10: A photomicrograph of transverse section of the left ventricular wall of a Dox- treated rat (Group III) exhibiting separated and fragmented cardiac muscle fibers $(*)$. Note deeply stained pyknotic nuclei $(\mathrm{N})$. Hx. \&E.; X 1000

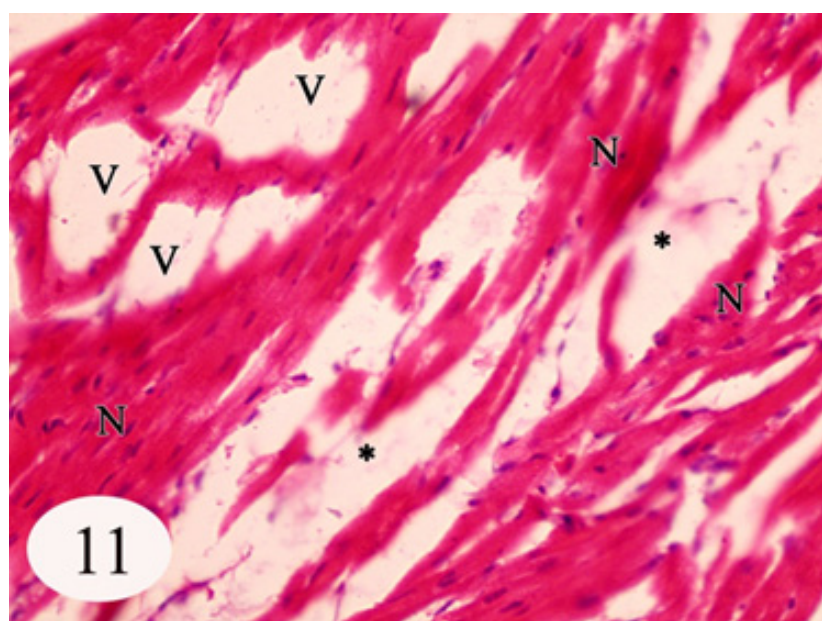

Fig. 11: A photomicrograph of a longitudinal section of the left ventricular wall of a Dox-treated rat (Group III) showing disorganized cardiac muscle fibers $(*)$ containing many deeplystained irregular nuclei (N) with extensive vacuolations (V). Hx.\&E.;X1000 


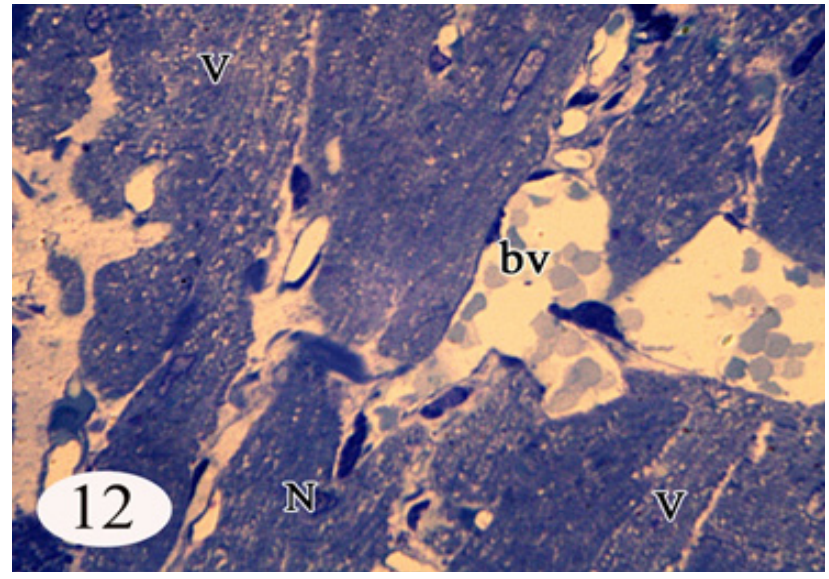

Fig. 12: A photomicrograph of a longitudinal semithin section of the left ventricular wall of a Dox- treated rat (Group III) showing fragmented and disrupted striated cardiac muscle fibers with extensive vacuolations (V). Note: nuclei with irregular shaped nuclei $(\mathrm{N})$ and dilated and congested blood vessels (bv). Toluidine blue;

$\mathrm{X} 1000$

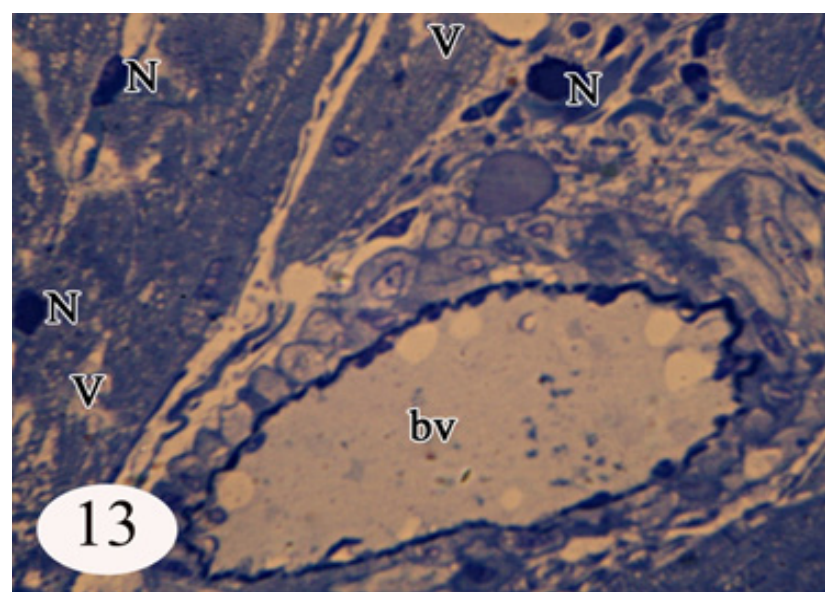

Fig. 13: A photomicrograph of a longitudinal semithin section of the left ventricular wall of a Dox-treated rat (group III) revealing extensive vacuolization (v) of the cardiomyocytes with loss of myofibrils. Note: dense irregular nuclei $(\mathrm{N})$ and severely dilated blood vessel (bv). Toluidine blue;

$\mathrm{X} 1000$

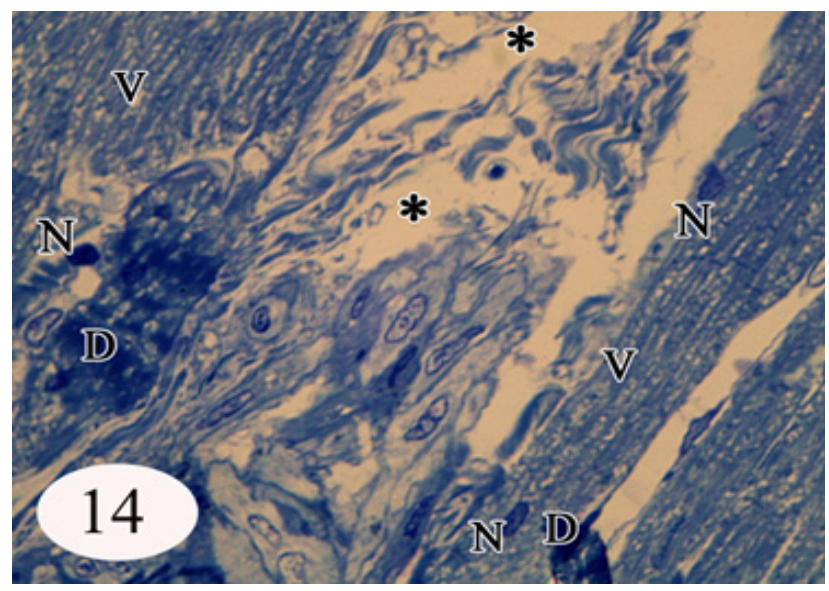

Fig. 14: A photomicrograph of a longitudinal semithin section of the left ventricular wall of a Dox-treated rat (group III) showing disrupted myofibrils architecture with cardiomyocytic vacuolization (v) and loss of myofibrils (*). Note: distorted- nuclei (N) and dense bodies (D). Toluidine blue;

$\mathrm{X} 1000$

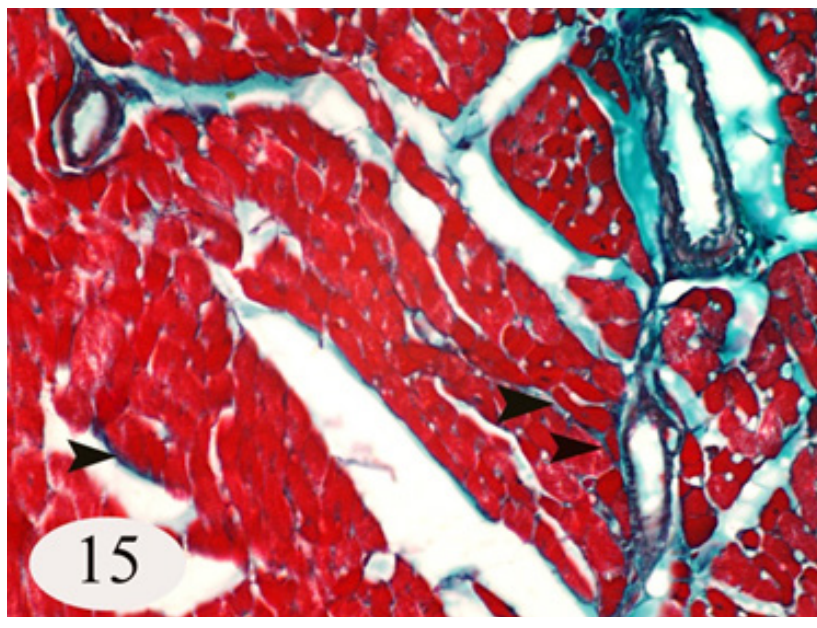

Fig. 15: A photomicrograph of a transverse section of the left ventricular wall of a Dox-treated rat (group III) showing an increased amount of collagen fibers (arrowheads) between the cardiac myocytes. Masson's Trichrome;

$\mathrm{X} 1000$

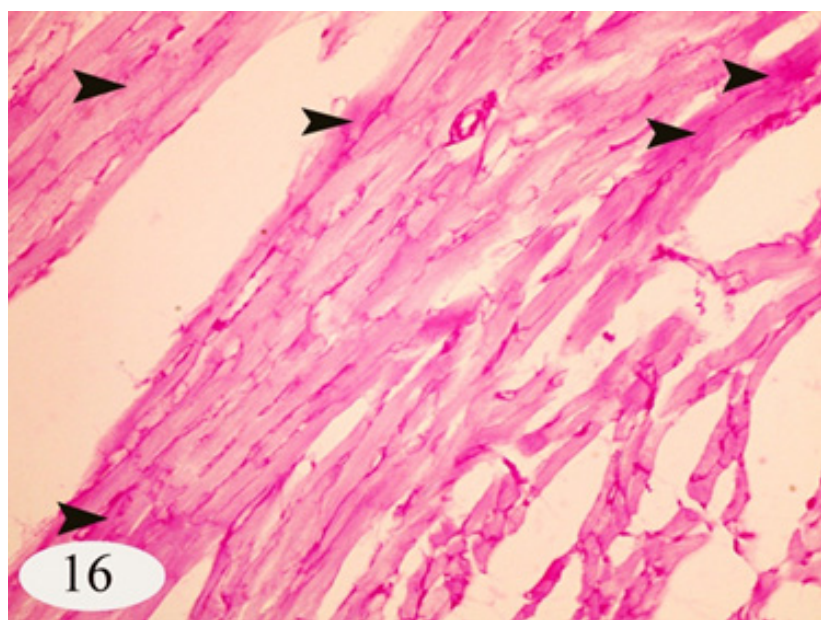

Fig. 16: A photomicrograph of a transverse section of the left ventricular wall of a Dox-treated rat (group III) showing a very strong positive reaction (arrowheads).

PAS;X1000

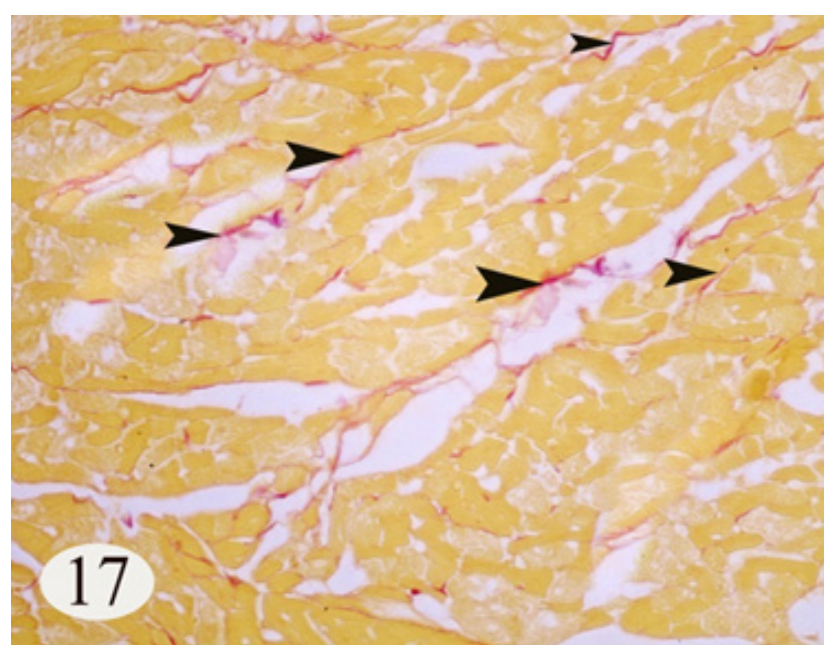

Fig.17: A photomicrograph of a transverse section of the left ventricular wall of a Dox-treated rat (group III) showing a remarkable increase in the amount of collagen fibers (arrowheads) between the cardiac muscle fibers. Van Gieson x 1000 


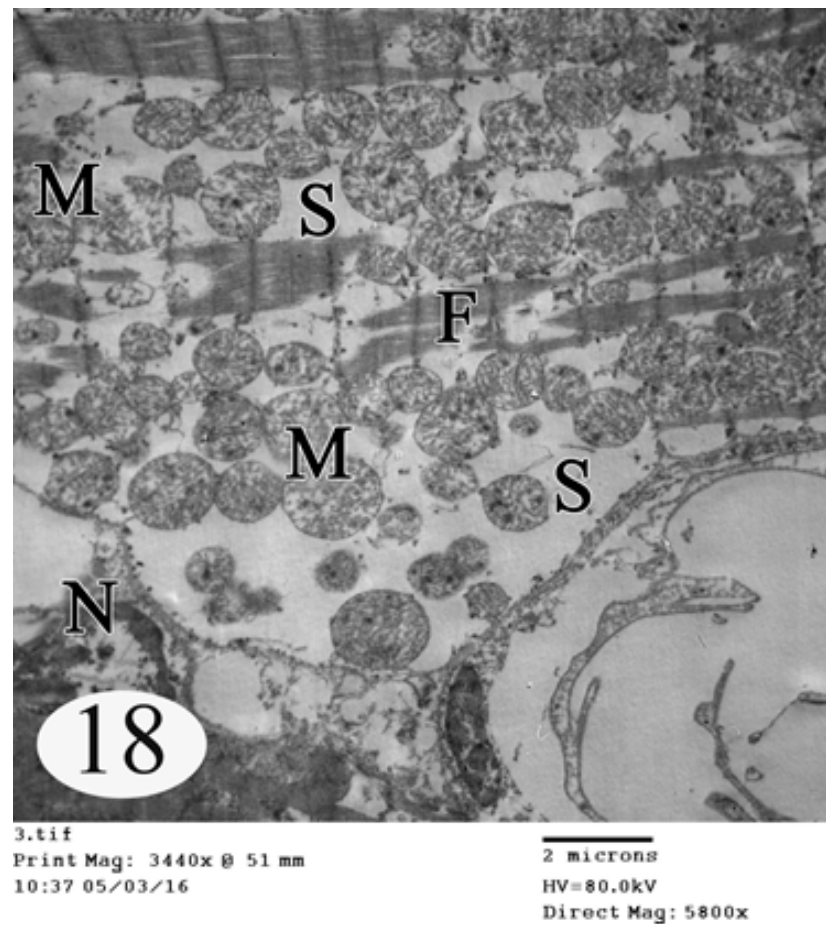

Fig. 18: An electron micrograph of a transverse section of the left ventricular wall of a Dox-treated rat (group III) showing disorganized fragmented myofibrils with loss of cross striations (F). It also reveals irregularly arranged degenerated mitochondria with ruptured membrane (M) and wide spaces (S) in the sarcoplasm of the cardiac myocytes. Notice the abnormal shaped nucleus $(\mathrm{N})$ with peripheral chromatin condensation.

X 5800

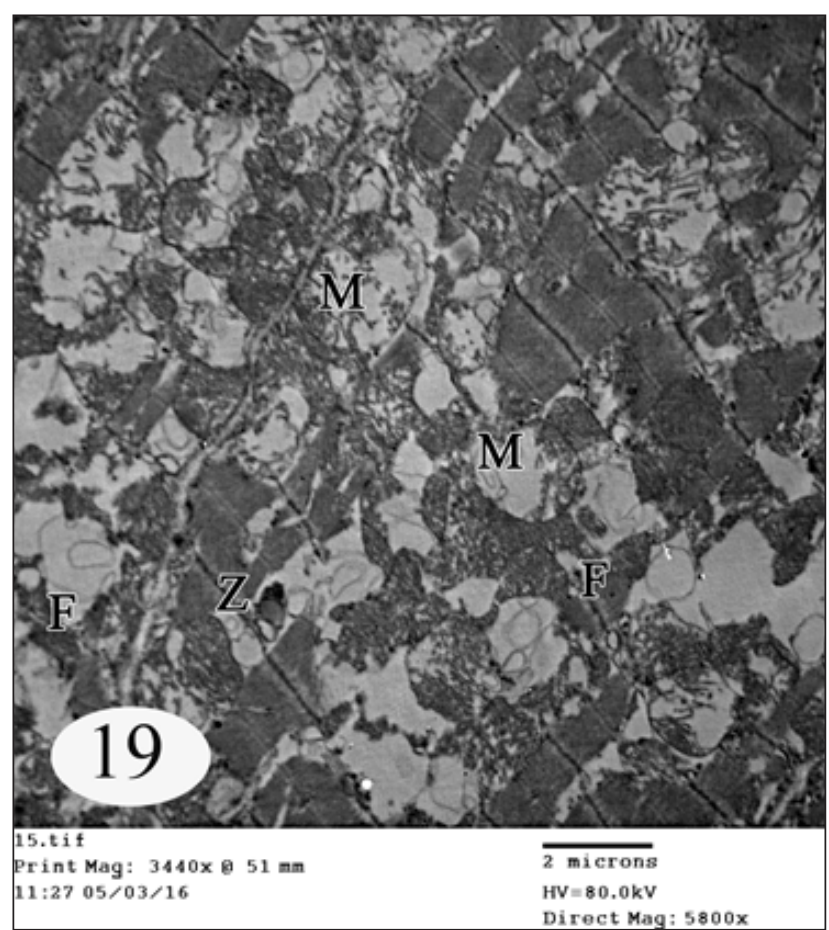

Fig. 19: An electron micrograph of a transverse section of the left ventricular wall of a Dox-treated rat (group III) showing marked degenerated and destructed myofibrils, irregular orientation of the sarcomeres $(\mathrm{F})$, degenerated mitochondria $(\mathrm{M})$ with ruptured membranes and areas of interrupted $\mathrm{Z}$ lines $(\mathrm{Z})$.

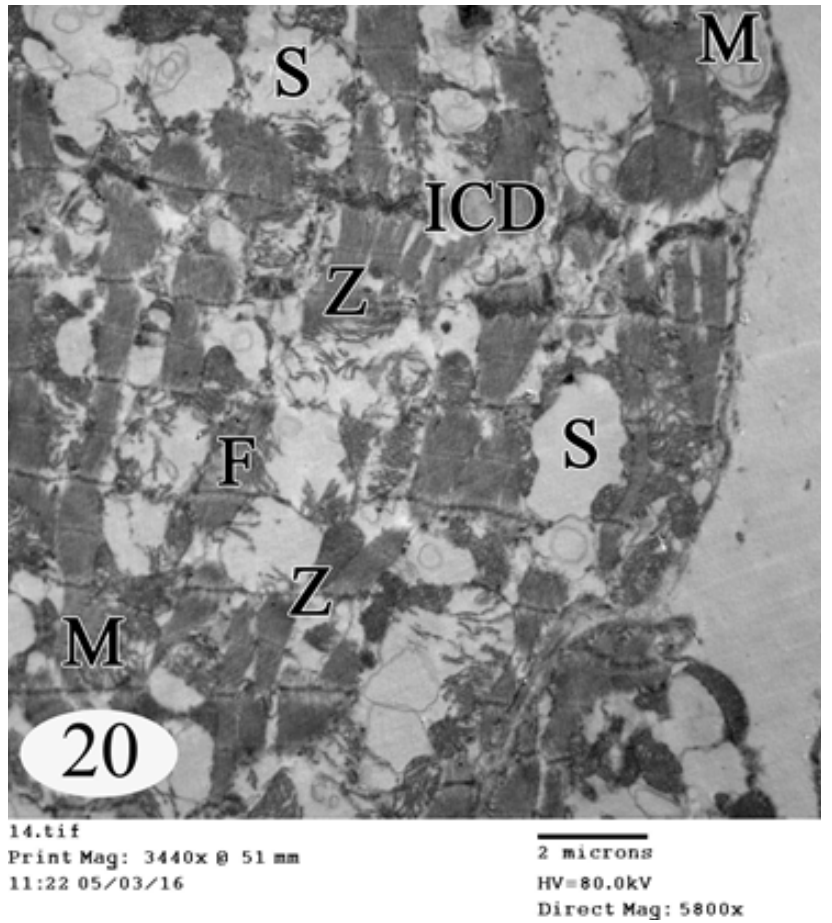

Fig. 20: An electron micrograph of a transverse section of the left ventricular wall of a Dox-treated rat (group III) showing degenerated and destructed myofibrils (F), irregular orientation of the sarcomeres, degenerated mitochondria $(\mathrm{M})$ with ruptured membranes and areas of interrupted $\mathrm{Z}$ lines $(\mathrm{Z})$. Note the disrupted intercalated disc (ICD) and multiple spaces $(\mathrm{S})$.

X 5800

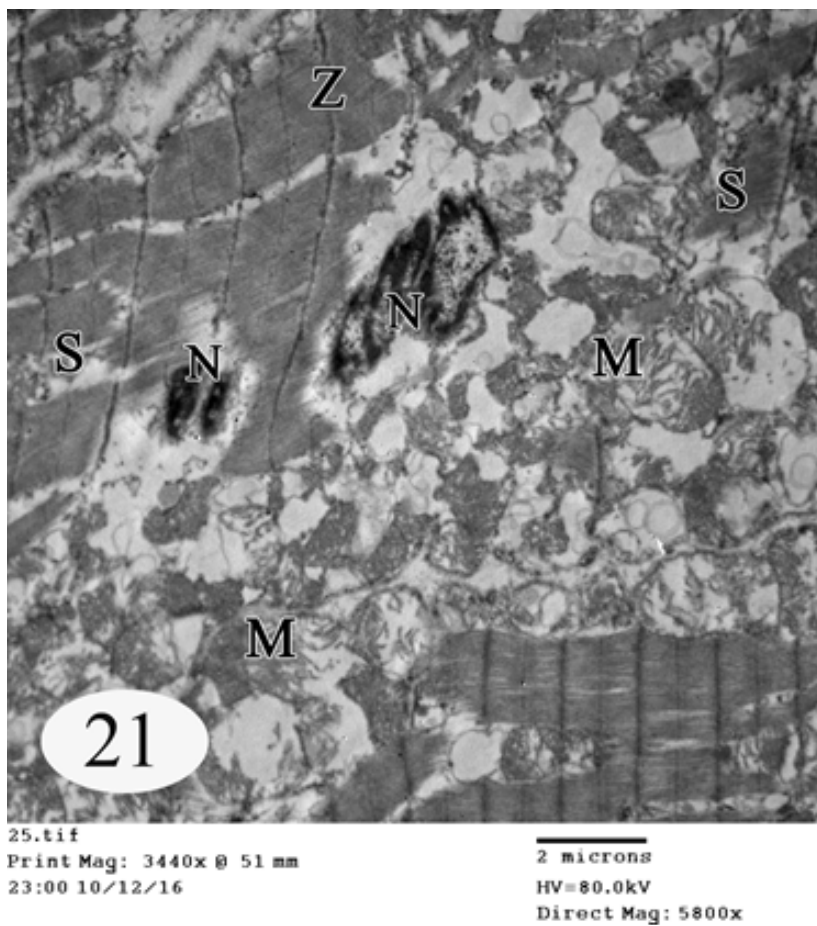

Fig. 21: An electron micrograph of the left ventricular wall of a Dox treated rat (Group III) showing fragmented and widely separated myofibrils, sarcomeres $(\mathrm{S})$ containing abnormally small nuclei $(\mathrm{N})$ and degenerated mitochondria $(\mathrm{M})$ with ruptured membranes and destructed cristae. Focal preservation of $\mathrm{Z}$ lines $(\mathrm{Z})$ can be observed.

X5800 


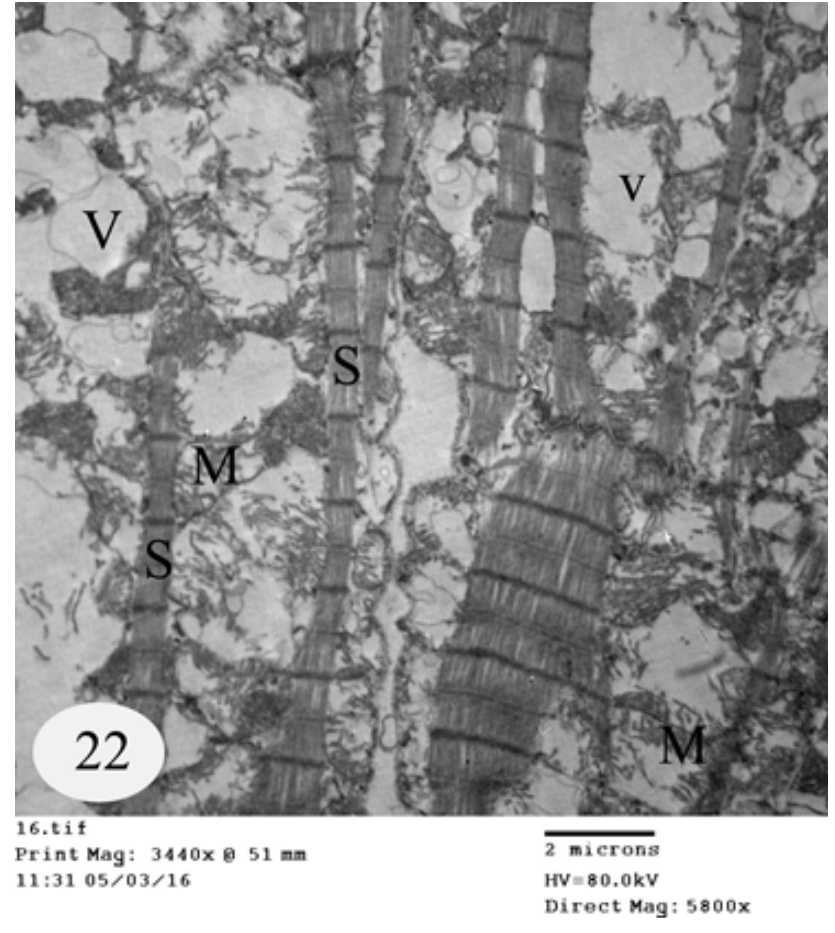

Fig. 22: An electron micrograph of the left ventricular wall of a Doxtreated rat (Group III) showing shortening of the sarcomeres (S) and multiple vacuolations (V). Degenerated mitochondria (M) with ruptured membrane and disrupted cristae are seen.

X5800

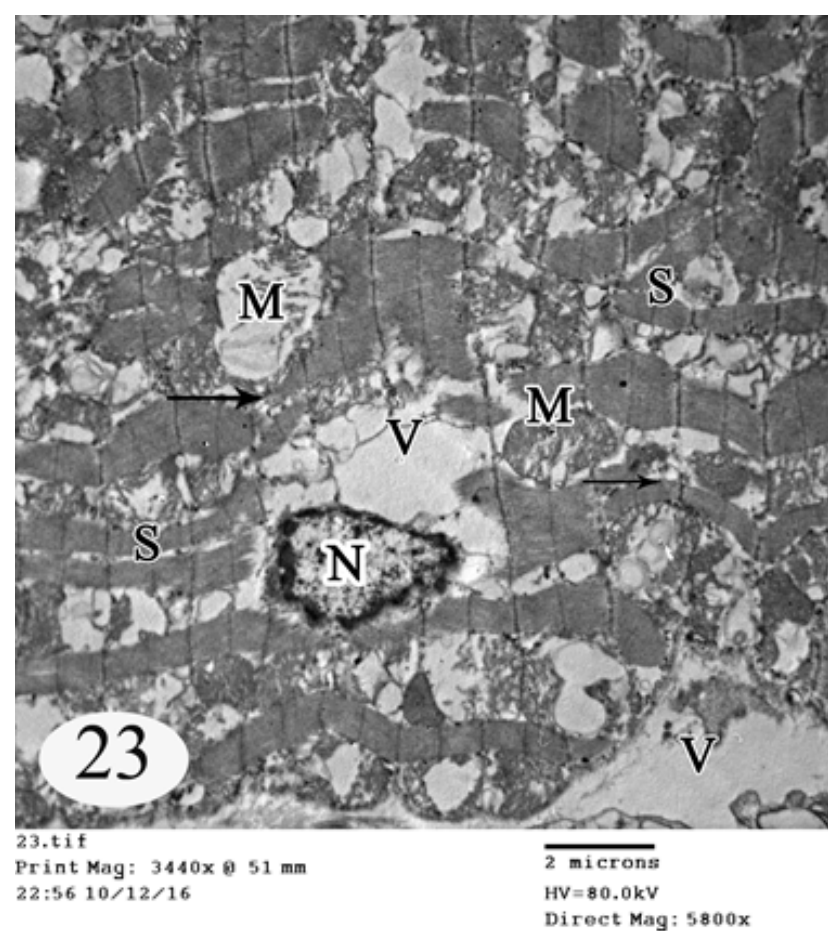

Fig. 23: An electron micrograph of the left ventricular wall of a Dox-treated (group III) showing extensive vacuolization (V) of the cardiomyocytes with loss of myofibrils and shortening of sarcomeres (S) and loss of sarcolemma (arrow). Note: severely destructed degenerated ruptured mitochondria $(\mathrm{M})$ and distorted nucleus $(\mathrm{N})$ with peripheral chromatin condensation.

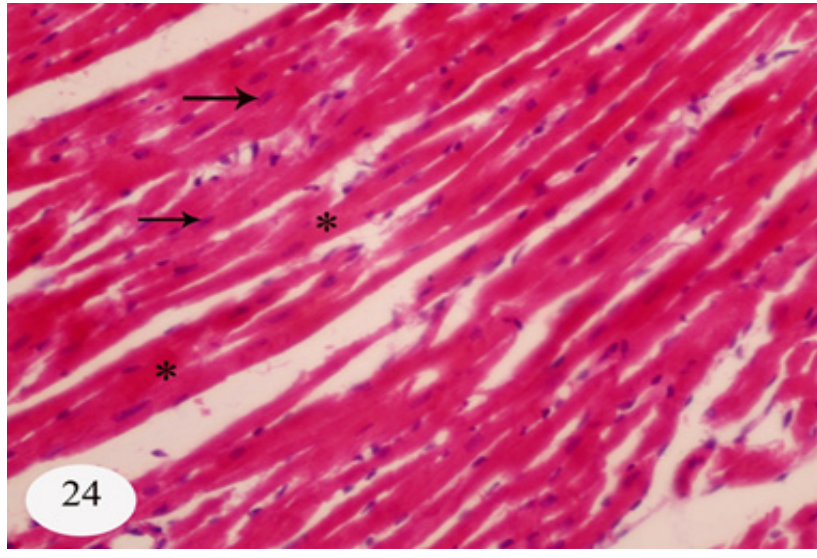

Fig. 24: A photomicrograph of the left ventricular wall of a Dox+Vitamin E treated rat (Group IV) showing the cardiac muscle fibers with more or less normal appearance. They contain central oval vesicular nuclei $(\mathrm{N})$ and deeply-stained acidophilic sarcoplasm. Hx.\&E.;X 1000

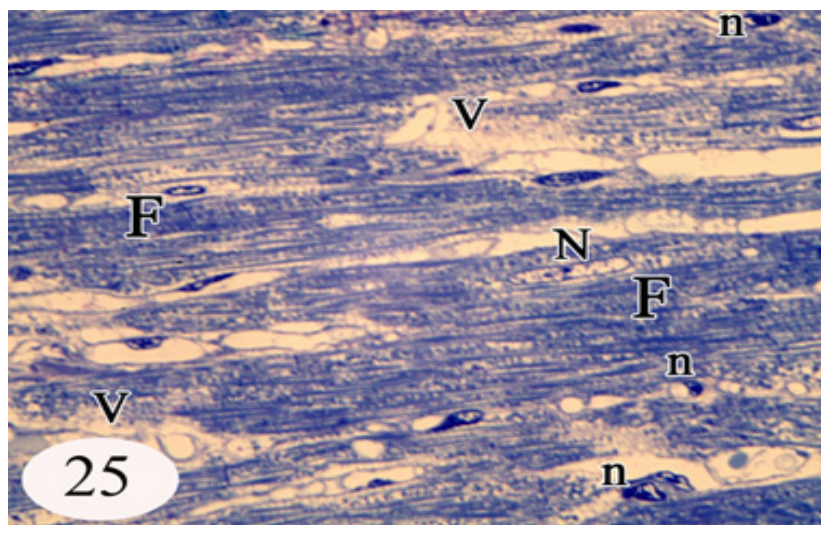

Fig. 25: A photomicrograph of a semithin section in the left ventricular wall of a Dox+Vitamin E treated rat (Group IV) showing more or less normal cardiac muscle fibers $(\mathrm{F})$ with vesicular nuclei $(\mathrm{N})$. Residual vacuolations $(\mathrm{V})$ between the cardiomyocytes and distorted shaped nuclei (n) are seen. Toluidine blue; X 1000

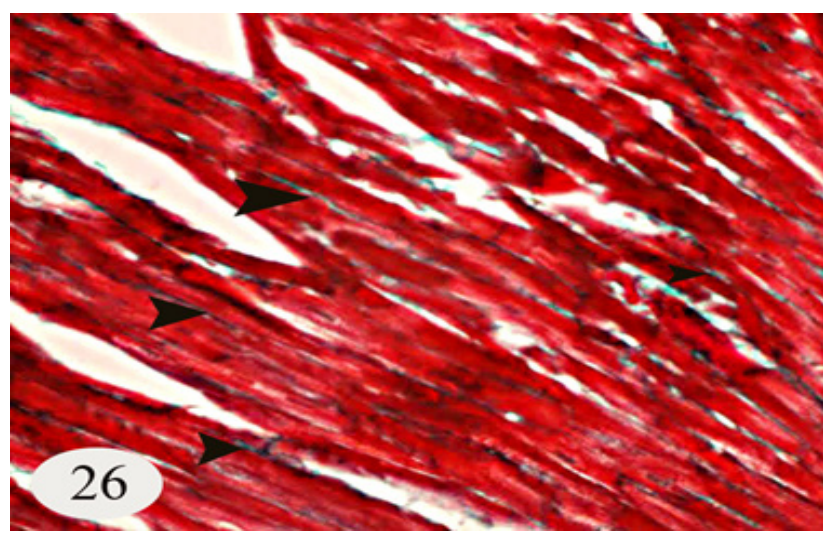

Fig. 26: A photomicrograph of a section of the left ventricular wall of a Dox+ Vitamin E rat (Group IV) showing general structure more or less similar to control. Notice the minimal amount of collagen fibers (arrowheads).
Masson's Trichrome; X 1000 


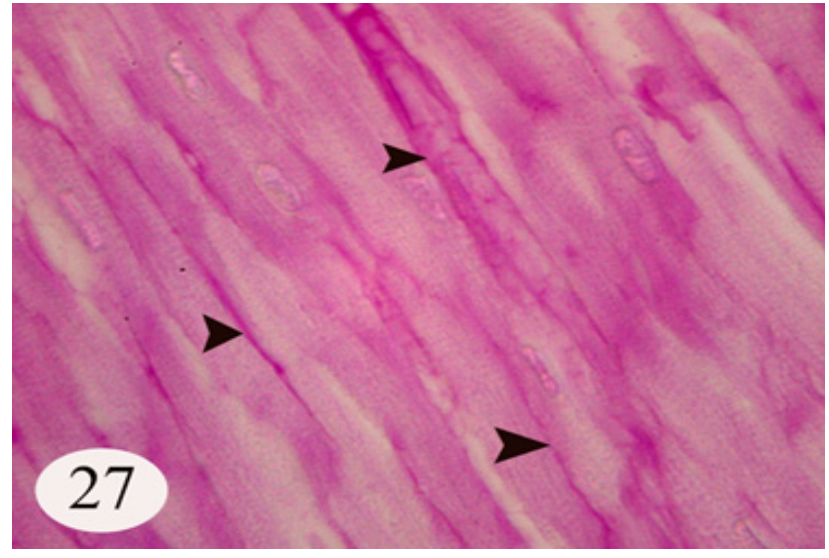

Fig. 27: A photomicrograph of a section of the left ventricular wall of a Dox+Vitamin E rat (Group IV) showing positive reaction (arrowheads). PAS;

$\mathrm{X} 1000$

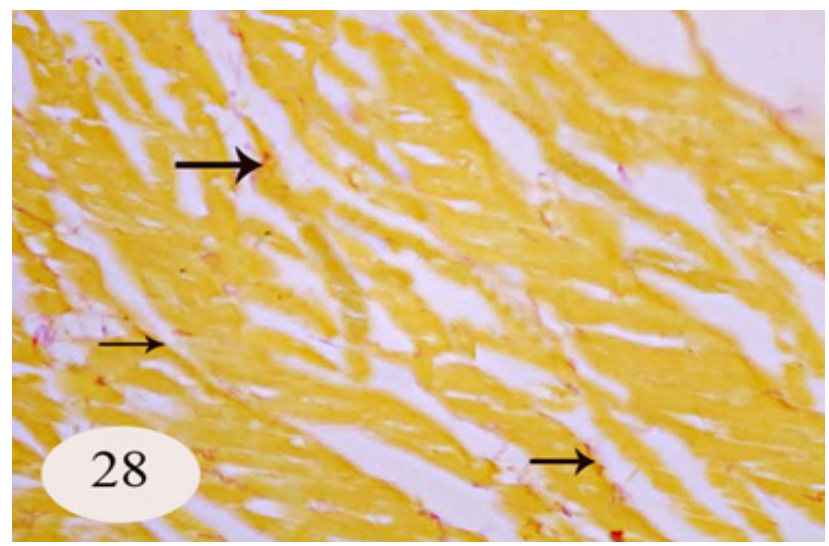

Fig. 28: A photomicrograph of a section of the left ventricular wall of a Dox+Vitamin E treated rat (Group IV) showing very minimal amount of collagen fibers (arrows).

Van Gieson; X1000

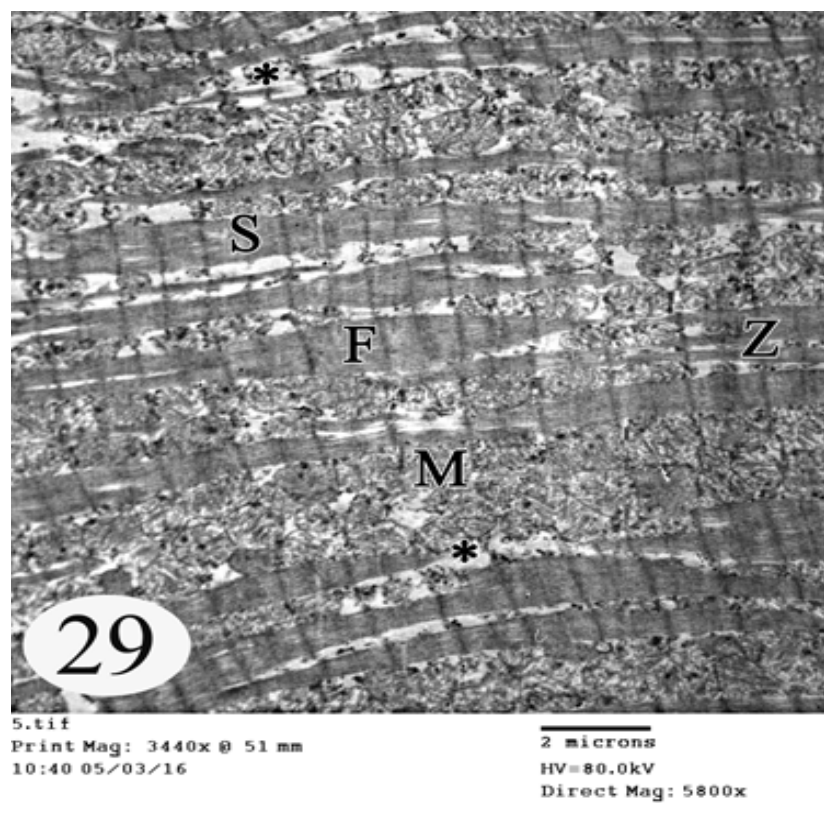

Fig. 29: An electron micrograph of a section of the left ventricular wall of a Dox+Vitamin E treated rat (Group IV) showing regularly arranged myofibrils (F) between $\mathrm{Z}$ lines $(\mathrm{Z})$, regularly arranged mitochondria $(\mathrm{M})$ and well oriented sarcomeres (S). Note few discontinued myofibrils $(*)$

$\mathrm{X} 5800$

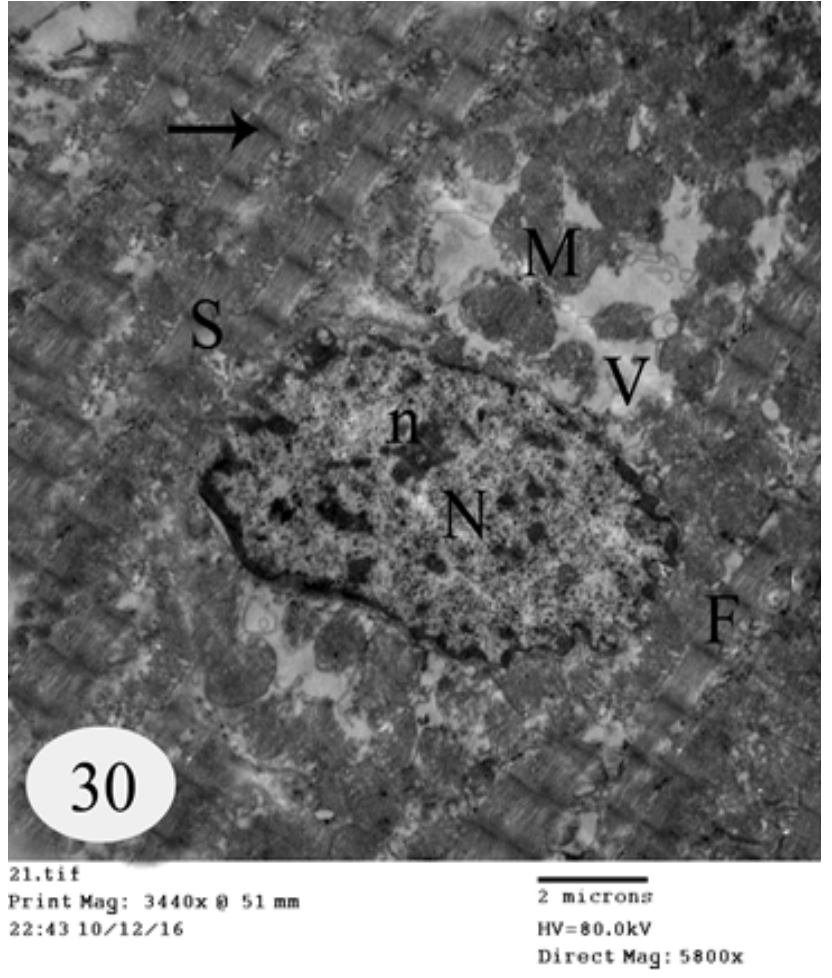

Fig. 30: An electron micrograph of a section of the left ventricular wall of a Dox+Vitamin E treated rat (Group IV) showing regularly arranged sarcomeres (S), more or less normal myofibrils $(\mathrm{F})$ and $\mathrm{Z}$ lines (arrow), a nucleus $(\mathrm{N})$ with prominent nucleolus $(\mathrm{n})$, peripheral heterochromatin condensation and irregular outline. Note condensed mitochondria (M) and residual vacuolation $(\mathrm{V})$.

$\mathrm{X} 5800$

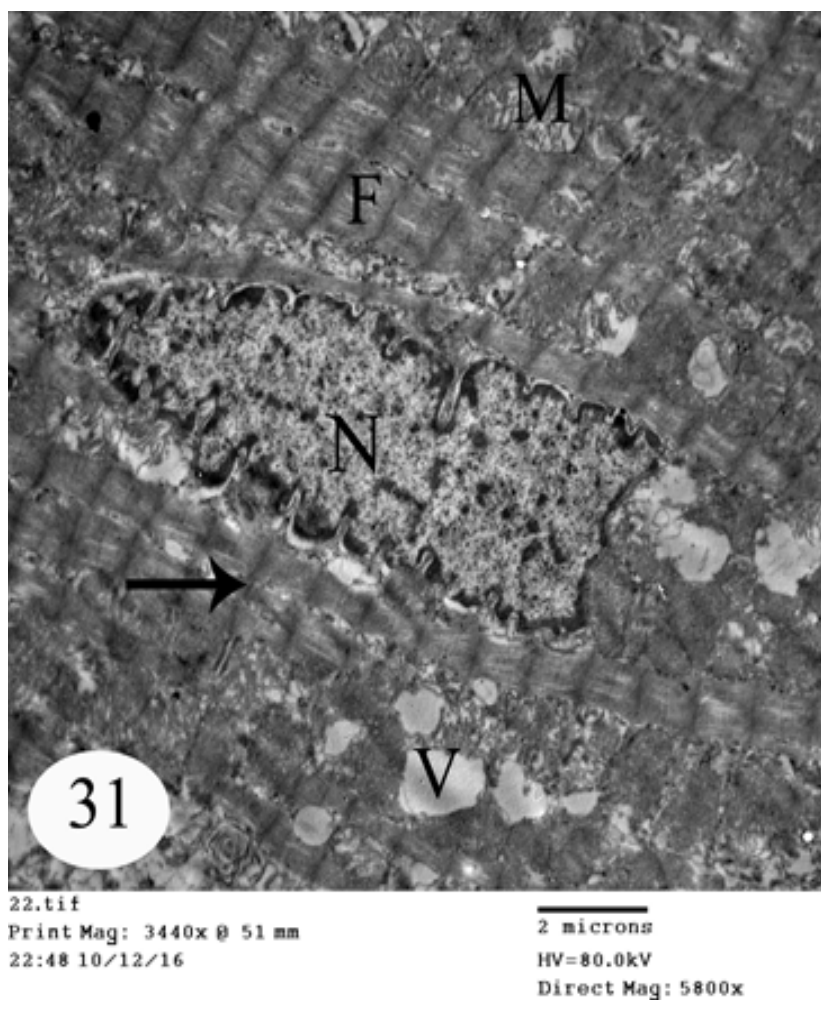

Fig. 31: An electron micrograph of a section of the left ventricular wall of a Dox+Vitamin E treated rat (Group IV) showing more or less norma fibrils (F), $\mathrm{Z}$ lines (arrow) and rows of mitochondria (M). Multiple vacuoles $(\mathrm{V})$ and infolded nucleus $(\mathrm{N})$ with heterochromatin are also seen X5800 
Table 1: Levels of total antioxidant capacity (TAC), triglycerides, total cholesterol, HDL-C, Lactate dehydrogenase (LDH) and creatine kinase (CK) in different groups.

\begin{tabular}{|c|c|c|c|c|}
\hline & $\begin{array}{l}\text { Negative Control } \\
\text { Group } \\
\text { (Group I, } n=10)\end{array}$ & $\begin{array}{l}\text { Positive Control } \\
\text { Group } \\
\text { (Group II, } \mathrm{n}=10 \text { ) }\end{array}$ & $\begin{array}{c}\text { Dox-treated } \\
\text { Group } \\
\text { (Group III, } \mathrm{n}=10)\end{array}$ & $\begin{array}{c}\text { Dox }+ \text { Vitamin E } \\
\text { Group } \\
\text { (Group IV, } \mathrm{n}=10)\end{array}$ \\
\hline TAC $(\mathrm{mM} / \mathrm{L})$ & $0.908 \pm 0.05$ & $0.907 \pm 0.06$ & $0.336 \pm 0.04^{\mathrm{a}}$ & $0.758 \pm 1.30^{\mathrm{b}}$ \\
\hline Triglycerides (mg/dL) & $169.3 \pm 6.5$ & $168.9 \pm 7.2$ & $187.17 \pm 5.9^{\mathrm{a}}$ & $163.8 \pm 7.8^{\mathrm{b}}$ \\
\hline Total cholesterol (mg/dL) & $157.8 \pm 10.1$ & $157.8 \pm 8.2$ & $183.5 \pm 11.1^{\mathrm{a}}$ & $157.5 \pm 13.3^{\mathrm{b}}$ \\
\hline HDL-C (mg/dL) & $56.5 \pm 7.5$ & $56.5 \pm 6.8$ & $44.0 \pm 3.7^{\mathrm{a}}$ & $58.7 \pm 3.6^{\mathrm{b}}$ \\
\hline $\mathrm{LDH}(\mathrm{U} / \mathrm{L})$ & $76.50 \pm 10.6$ & $76.50 \pm 9.8$ & $95.47 \pm 6.8^{\mathrm{a}}$ & $70.67 \pm 9.0^{\mathrm{b}}$ \\
\hline CK (U/L) & $195.8 \pm 10.8$ & $195.7 \pm 9.8$ & $313.8 \pm 11.7^{\mathrm{a}}$ & $242.8 \pm 5.5^{\mathrm{a}, \mathrm{b}}$ \\
\hline
\end{tabular}

Data are presented as means $\pm \mathrm{SD}$

a Significant when compared with control groups $p \leq 0.05$

b Significant when compared with Dox-treated group $p \leq 0.05$

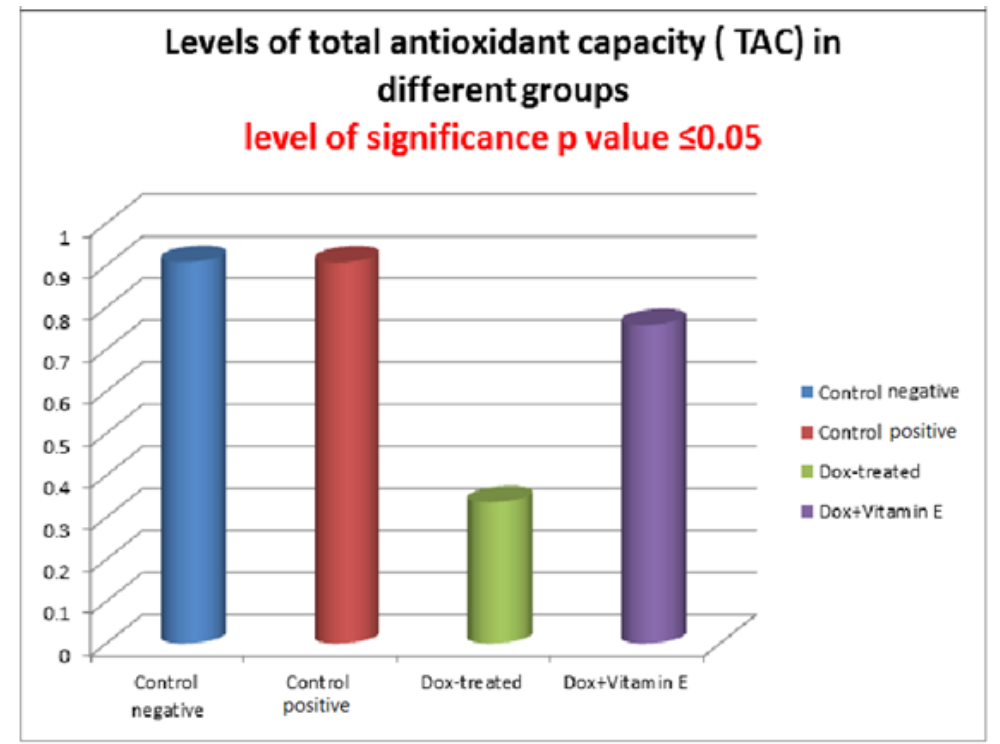

Histogram 1: Showing levels of total antioxidant capacity (TAC) in the different groups

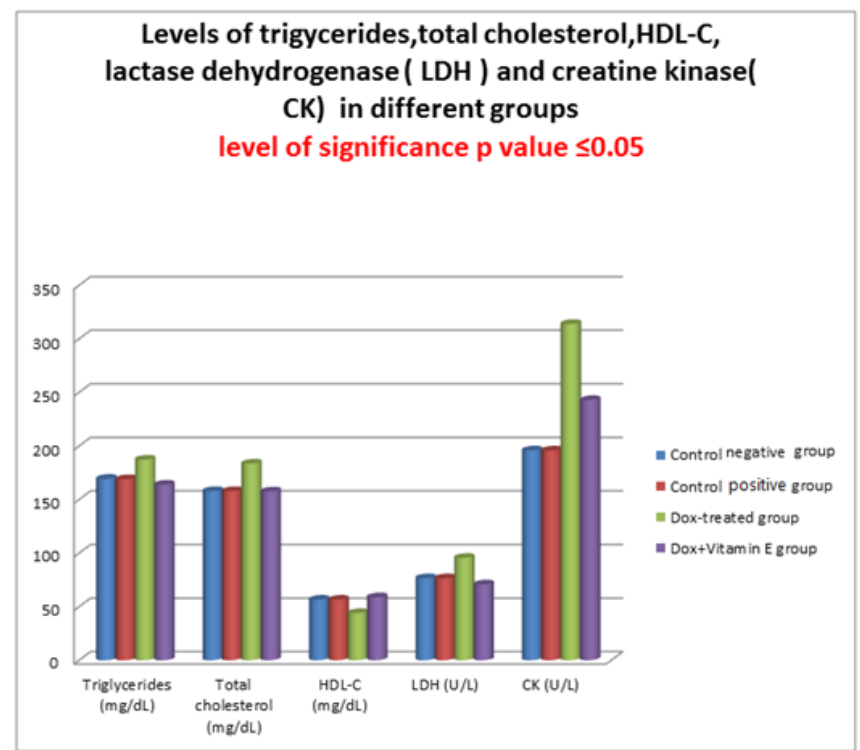

Histogram 2: Showing triglycerides, total cholesterol, HDL-C, Lactate dehydrogenase (LDH) and creatine kinase (CK) in the different groups. 


\section{DISCUSSION}

Cardiovascular complications can be caused by cancer chemotherapy or radiotherapy ${ }^{[12]}$. Anthracycline compounds is claimed to be the primary cause of chemotherapy-induced cardiotoxicity. The avoidance of anthracycline-induced cardiotoxicity is becoming an interdisciplinary point of interest and an important challenge in cancer survivorship due to the aging and development of the population and progresses in early detection and treatment especially that the number of cancer survivors continues to rise ${ }^{[13,14]}$.

Although Dox is a powerful and broadly used anthracycline antibiotic for the treatment of many types of malignancies, its clinical usefulness is often constrained due to the precipitation of organ toxicity, specially, the increased probability for the dilated cardiomyopathy development. In the light of these findings, major attention has been warranted from the physicians as well as researchers to seek for protective agents to counteract the deleterious effects of Dox on the healthy myocardium. The characters for the ideal cardioprotective agents are not compromising the clinical efficiency of Dox and lacking cumulative or irreversible toxicity on the tissues ${ }^{[15,16]}$. The present study was established to assess the possible protective role of Vitamin E against doxorubicin-induced cardiomyopathic changes by light, ultra structural and biochemical studies.

After reviewing light and electron microscopic results of the current study, it was declared that Dox had detrimental effects on the structure of the myocardium and lead to myocardial injury. The affection was extensive and revealed many degenerative changes in the form of disorganization, prominent vacuolization, loss of myofibrils and myocytolysis which were the distinctive features of cardiotoxicity induced by Dox. The results of the current investigation were strongly supported by Sacco et al..$^{[17]}$ and Nakamura et al. ${ }^{18]}$ and explained by Chugun et al. ${ }^{[19]}$ who proposed that sarcoplasmic reticulum dysfunction progressed after the Dox treatment completion and augments the Dox-induced late cardiotoxicity. It also came in accordance with ${ }^{[20,21]}$ whose results were in the same line.

In the present work, the dense bodies appeared in the semithin sections stained with Toluidine blue might disrup $\mathrm{Z}$ band material as previously explained by Lushnikova and others ${ }^{[22]}$.

The present work, exhibited that Dox induced cardiomyocytic apoptosis. The H \& E stained sections revealed myocytes with increased cytoplasmic eosinophilia and the nuclei showed a peripherally marginated chromatin. This is consistent with the findings of semithin and ultrastructural sections and confirmed by the findings of Mukherjee et al. ${ }^{[23]}$ who reported that Dox- induced changes in cardiomyocytes were characterized by deformation of nuclei and margination of nuclear chromatin.
These findings are coincided with the current electron microscopic results where the characteristic shape of chromatin condensation observed in the cardiomyocytic nuclei and condensed mitochondria were considered, according to Mukherjee et al. ${ }^{[23]}$ and Hayakawa et al. ${ }^{[24]}$ as typical features of apoptosis.

Furthermore, Lushnikova et al. ${ }^{[25]}$ confirmed that after Dox injection, the cardiac muscle revealed deformity, nuclear fragmentation and peripheral chromatin condensation. Moustafa and Shalaby ${ }^{[26]}$ elucidated that myocardial apoptosis developed as a common pathway of Dox-induced cardiotoxicity.

In the present study, using light microscopy, the hearts of Dox-treated rats revealed marked vascular congestion in between cardiac myocytes. This corresponded with the other investigators' work ${ }^{[27]}$ who observed obvious amount of blood cells in widely pericapillary spaces among the disrupted myocardial cells.

On the ultrastructural level, the results of the current work showed mitochondrial degenerative changes, myofibrillar disorganization and degeneration. Severe mitochondrial morphological changes, and disruption and dissolution of myofibrils were observed with acute and cumulative doses of doxorubicin[ ${ }^{27,28]}$.

The noticeable development of cytoplasmic vacuoles might be attributed to an expansion of the cell membranes caused by water and electrolytes imbalance ${ }^{[29]}$. However, this could be attributed to dilatation of the granular sarcoplasmic reticulum as mentioned by Lushnikova et $a l .{ }^{[25]}$.

In regard to the biochemical changes, the current study revealed that after Dox administration, rats showed marked cardiotoxicity represented in the increased levels of myocardial injury markers. Estimation of the level of TAC revealed a significant decrease in the cardiac tissue of Doxtreated group. Also, a significant increased serum level of creatine kinase, LDH and CK was declared. Serum levels of triglyceride and total cholesterol were significantly increased in comparison to the control group. The present findings are in accordance with those stated by Abeer et $a l{ }^{[30]}$. On the other hand, the concomitant treatment with Vitamin E and Dox had resulted in a reversal of the cardiac enzymatic activity towards the normal levels.

For explanation of Dox-cardiotoxicity, a lot of mechanisms have been postulated, among the most accepted ones are free radicals formation that induced lipid peroxidation, disrupted metabolism of the mitochondria by binding to its lipids and the direct toxic effect on cardiac muscle $^{[31,32]}$.

The cardiac muscle is mainly vulnerable to the injurious effect of the free radicals due to less free radical antioxidant factors in comparison to organs like kidney or liver. Also, cardiolipin in the heart cells' mitochondrial 
membranes attracts Dox causing its accumulation inside the myocardial cells ${ }^{[33]}$.

Researches have been piloted on ascorbic acid and Clarithromycin in order to prevent the hazardous impact of Dox on the cardiac muscle ${ }^{[34,35]}$.

On the other hand, the present results of the rats treated with Dox and Vitamin E revealed an obvious reduction in the histopathological changes induced by Dox represented in the great extent preservation of cardiac myofibrils' organization and the reduction of the vascular congestion and necrotic changes of cardiac myocytes compared with the Dox-treated group. This comes in agreement of many investigators who confirmed that Vitamin E ameliorated myocardial toxicity induced by Doxorubicin ${ }^{[36,37]}$. As regard the biochemical measures, the current study declared that the concomitant treatment with Vitamin E and Dox had resulted in a reversal of the cardiac enzymatic activity towards the normal levels. With pre and concomitant treatment with Vitamin $\mathrm{E}$ there was a significant reduction in serum creatine kinase $(\mathrm{CK})$, Lactate dehydrogenase (LDH), triglyceride and total cholesterol. These findings come in agreement with the findings of Abbas and $\mathrm{Sakr}^{[38]}$ who studied the anti-oxidative effect of Vitamin $E$ on the cardiac tissue.

From the present study, Vitamin E treatment, before and concurrent with doxorubicin injections, markedly attenuated Dox-induced myocardial injury.

\section{CONCLUSION}

Finally, the present study postulated that the Dox causes cardiotoxicity. It is concluded also that Vitamin E could be deliberated as an effective candidate in combination with Dox to limit heart injury.

\section{CONFLICT OF INTEREST}

The authors declare that there is no conflict of interest.

\section{REFERENCES}

1. Siegel, R., Ma, J., Zou, Z. and Jemal, A. (2018): Cancer statistics, CA Cancer J. Clin. 64:9-29.

2. Shivakumar, M., Rani, A. and Reddy, Y. (2012): A Study on the Toxic Effects of Doxorubicin on the Histology of Certain Organs. Toxicol. Int. 19(3): 241-244.

3. Abullaev, F., Luna, R., Roitenburd, B. and Espinosa, A. (2000): Pattern of childhood cancer mortality in Mexico. Arch. Med. Res. 31:526-531.

4. Zhang, Y., Shi, J., Li, Y. and Wei, L. (2009): Cardiomyocyte death in doxorubicin-induced cardiotoxicity. Arch. Immunol. Ther. Exp. 57(6): $435-445$.

5. Standring, S., Neel, A., Girish, J., Patricia, C., Alan, R. and Caroline, B. (2016): Gray's Anatomy, $41^{\text {th }}$ Ed. Ch.; 6.
6. Hanaa, H., Fathia, M., Gamal, A. and Senot H. (2005): Cardioprotective activity of melatonin and its novel synthesized derivatives on doxorubicininduced cardiotoxicity. Bioorg. Med. Chem. 13:1847-1857.

7. Koti, B., Vishwanathaswamy, A., Wagwade, J. and Thippeswamy A. (2009): Cardioprotective effect of lipistat against doxorubicin induced myocardial toxicity in albino rats. Indian J. Exp. Biol. 47:41-46.

8. Nuria,M., Pablo,J., Antonia, A. and Fernando, R. (2016): Antioxidant Intake and Antitumor Therapy: Toward Nutritional Recommendations for Optimal Results.Pp:1-19.

9. Puri, S. (2001): Cardioprotective. Effect of Vitamin $\mathrm{E}$ in doxorubicin induced acute cardiotoxicity in rats. J. Indian Assoc. Pediatric. Surg. 6: 112-118.

10. Koracevic, D., Koracevic, G., Djordjevic, V., Andrejevic, S. and Cosic V. (2001): Method for the measurement of antioxidant activity in human fluids. J. Clin. Pathol. 54: 356-361.

11. Bancroft, J. D. and Gamble, M. (2008): Theory and practice of histological techniques. 6th ed. London: Churchill Livingstone.

12. De Santis, C., Lin, C., Mariotto, A., Siegel, R., Stein, K., Kramer, J., Alteri, R., Robbins, A. and Jemal, A. (2014): Cancer treatment and survivorship statistics. CA Cancer J. Clin. 64:252271 .

13. Vejpongsa, P. and Yeh, E. (2014): Prevention of anthracycline-induced cardiotoxicity: challenges and opportunities. J. Am. Coll. Cardiol. 64:938945 .

14. Angelis, A., Urbanek, K., Cappetta, D., Piegari, E., Ciuffreda, P., Rivellino, A., Russo, R., Esposito, G., Rossi, F. and Berrino, L. (2016): Doxorubicin cardiotoxicity and target cells: a broader perspective, Cardio-Oncology. 2:2.

15. Shreesh, O., Hasan, A., Sameer, G., Umesh, B., Chandrgouda, R., Arya, D. and Mohanraj, R. (2016): Cardioprotective Potentials of PlantDerived Small Molecules against Doxorubicin Associated Cardiotoxicity Oxidative Medicine and Cellular Longevity. Pp:1-19.

16. Minotti, G., Menna, P., Salvatorelli, E., Cairo, G. and Gianni, L. (2004): Anthracyclines: molecular advances and pharmacologic developments in antitumor activity and cardiotoxicity. Pharmacol. Rev. 56:185-229.

17. Sacco, G., Bigioni, M., Evangelista, S., Manzini, S. and Maggi, C.A. (2003): Cardioprotective effects of zofinopril, a new angiotensin converting enzyme inhibitor, on doxorubicin-induced cardiotoxicity in the rat. Eur. J. Pharmacol. 414 (1): 71-78. 
18. Nakamura, T., Ueda, Y., Juan, Y., Katsuda, S., Takahashi, H. and Koh, E. (2000) Fas-mediated apoptosis in Adriamycin-induced cardiomyopathy in rats: in vivo study. Circulation. 102:572-578.

19. Chugun, A., Temma, K., Oyamada, T., Suzuki, N., Kamiya, Y., Hara, Y., Sasaki, T., Kondo, H. and Akera, T. (2000): Doxorubicin-induced late cardiotoxicity: delayed impairment of $\mathrm{Ca} 2+$ - handling mechanisms in the sarcoplasmic reticulum in the rat. Can. J. Physiol. Pharmacol. 78 (4): 329- 338.

20. Koh, E., Ueda, Y., Nakamura, T., Kobayashi, A., Katsuda, S. and Takahashi, H. (2002): Apoptosis in young rats with Adriamycin-induced cardiomyopathy-comparison with pirarubicin, a new anthracycline derivative. Ped. Res.51(2):256259.

21. Rahman, A., Alam, M., Rao, S., Cai, L., Clark, L., Shafiq, S. and Siddiqui, M. (2001): Differential effects of doxorubicin on atrial natriuretic peptide expression in vivo and in vitro. Biol. Res.34 (34):195-206.

22. Lushnikova, E., Klinnikova, M. and Molodykh, O. (2005): Ultrastructural criteria of cardiomyocyteregeneratory and plastic insufficiency in anthracyline cardiomyopathy. Bull. Exp. Biol. Med. 139 (4):472-476.

23. Mukherjee, S., Banerjee, S., Maulik, M., Dinda, A., Talwar, K. and Maulik, S. (2003): Protection against acute Adriamycin induced cardiotoxicity by garlic: Role of endogenous antioxidants and inhibition of TNF-alpha expression. BMC Pharmacol. (20):3-16.

24. Hayakawa, K., Takemura, G., Koda, M., Kawase, Y., Maruyama, R., Li, Y., Minatoguchi, S., Fujiwara, T. and Fujiwara, H. (2002): Sensitivity to apoptosis signal, clearance rate and ultrastructure of Fas ligand-induced apoptosis in in vivo adult cardiac cells. Circulation. 105:3039-3045.

25. Lushnikova, E., Nepomniashchich, L., Klinnikova, M. and Molodykh, O. (2005): Ultrastructural manifestations of disturbances of cardiomyocyte regeneration after the doxorubicin treatment. Morfologiia. 128(4):81-84.

26. Moustafa, A. and Shalaby, A. (2006): Impact of trimetazidine on doxorubicin-induced acute cardiotoxicity in mice: A biochemical and electron microscopic study. Egypt. J. Histol. 9(1):125-136.

27. Lien, Y., Lin, S., Nithipongvanitch, R., Oberley, T., Noel, T., Zhao, Q., Daosukho, C. and Clair, D. (2006) Tumor necrosis factor receptor deficiency exacerbated adriamycin-induced cardiomyocyte apoptosis: an insight into the Fas connection. Mol. Cancer Ther. 5(2):261-269.

28. Balli, E., Mete, U., Tuli, A., Tap, O. and Kaya, M. (2004): Effect of melatonin on the cardiotoxicity of doxorubicin. Histol.Histopathol. 19(4):1101-1108.

29. Abdelhadi, Z., Naeim, M., El-Wazir, Y., Ibrahim, M. and Hosny, S. (2015): Histological study on the effect of transplanted human umbilical cord blood CD34+ stem cells on albino rats subjected to myocardial infarction J. Afr. Ass. Physiol. Sci. $3(1): 49-57$.

30. Abeer, A., Sahar, K., Nermine, S. and Mahmoud, S. (2012): The Protective Role of Alpha-Lipoic Acid Against Doxorubicin-Induced Cardiotoxicity in Male Albino Rats (Light and Transmission Electron Microscopy Study). Egypt. J. Histol. 32(1):227-234.

31. Shalaby N. (2002): Ultrastructural study of the toxic effect of doxorubicin on cardiac muscle. Egypt. J. Histol. 25:155-167.

32. Koceva, C., Gwo, Ÿ., Kochman, A., Stolarska, A. and Jó, Z. (2003): Effects of pyrroline and pyrrolidine nitroxides on lipid peroxidation in heart tissue of rats treated with doxorubicin. Cell. Mol. Biol. Lett. 8(1):179-183.

33. Sarika, K., Mahalaxmi, M. and Sanjay, K. (2009): Protective Effect of SolanumTorvum on Doxorubicin-Induced Cardiac toxicity in Rats. Pharmacology online. 2:1192-1204.

34. Viswanatha, S., Wangikar, U. and Koti, B. (2011): Cardioprotective effect of ascorbic acid on doxorubicin-induced myocardial toxicity in rats. Indian J. Pharmacol. 43:507-511.

35. Mustafa, D., Fatih, F., Yasemin, I., Dolunay, G., Aziz, P., Ozmert, M., Yasar, E., Metin, A. and Barbaros, S. (2014): Cardioprotective Effect of Clarithromycin on Doxorubicin-Induced Cardiac Toxicity in Rats. International Journal of Hematology and Oncology. 1(24): 30-35.

36. Vijayudu, B., Harish, K., Venkatakrishnaiah, Y. and Majeswara, M. (2015): Impact of doxorubicin and vitamin $\mathrm{E}$, a separately and in combination on selected enzymatic activity levels involved in the energy metabolism in the major tissues of albino rat. International Journal of Advanced Research. 3(6):481-486.

37. Najah, H., Nasser, G., Fadhil, G., Bassim, I., adiq, J. (2012): Vitamin E and telmisartan attenuates doxorubicin-induced cardiac injury in rat through down-regulation of inflammatory response. BMC Cardiovasc. Disord.12:63. 
38. Abbas, A. and Sakr, H. (2013( Simvastatin and vitamin $\mathrm{E}$ effects on cardiac and hepatic oxidative stress in rats fed on high-fat diet. J. Physiol. Biochem. 69(4):737-750. 
الملخص العربى

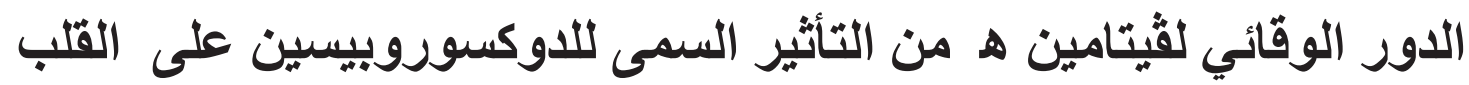

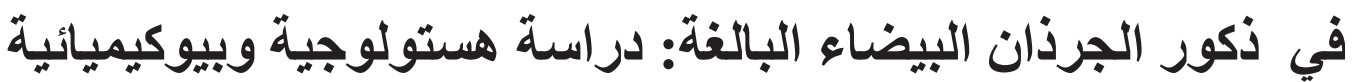

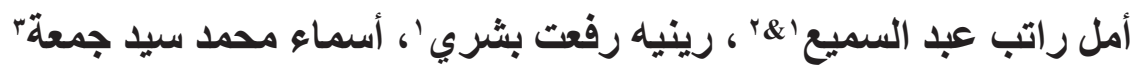

'قسم التثريح الآّمي وعلم الأجنة. كلية الطب - جامعة أسيوط

كقسم العلوم الأساسية ، جامعة الملك سعود بن عبد العزيز للعلوم الصحية ، الأحساء ، المملكة العربية السعودية

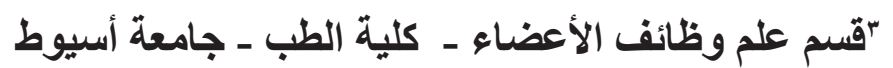

خلقية: يعتبر عقار دوكسوروبيسين (دوكس) قويا و فعالا في علاج السرطان. ومع ذللك فإن فائدته الاكلينيكية لا تز ال مقيدة بسبب تأثثر اته السمية على النسيج القلبي. يعتبرقيتامين هـ من مضادات الأكسدة المعروفة و المستخدمة كمكل غذائي.

الهدف من البحث: تقييم الدور الوقائي المحتمل لقيتامين هـ ضد التأثير ات السمية للدوكس على القلب. المواد وطرق البحث: أجرى هذا البحث على عدد أربعين من ذكور الجرذان البيضاء البالغة والتي تبلغ من العمر ثناثة أثنهر وتزن 200 - 250 جرام و التي تم تقسيمها إلى أربع مجموعات بو اقع 10 فئران لكل منها. المجموعة الأولى: تم استخدامها كمجمو عة ضابطة سالبة ولم تتلق أى علاج ـ المجمو عة الثانية : تم استخدامها كمجمو عة ضابطة موجبة وتم حقنها بجر عة 1 مل محلول ملحي تركيزه 9. 0 \% فى البريتون يو بيا لمدة أسبوع واحد. المجموعة الثالثة: نم حقنها فى البريتون بعقار الدوكس بجر عة 4 ملجم / كجم من وزن الجسم يوميًا لمدة أسبوع و احد. المجموعة الر ابعة: تم اعطائها ثيتامين هـ بجر عة 100 ملجم / كجم من وزن الجسم عن طريق الفم يو ميًا لمدة أسبو عين ثم تم حقنها بعقار الدوكس بنفس الجرعة و الطريقة كما هو مبين في المجمو عة الثالثة مع استمر ار اعطائها قيتامين هـ عن طريق الفم أثناء فترة الحقن ـ تم تخدير الحيو انات وتم أخذ عينات دم من المجمو عات الأربعة لتحديد مستويات ناز عة هيدروجين اللاكتات و الكرياتين كيناز و الدهون الثناثية و الكوليسترول الكلي و البروتين الدهني عالي الكثافة. ثم تمت التضحية بالحيو انات من المجموعات الأربعة وتم استخدام جزء من القلب لتحديد المستوى الكلي لقدرة الأكسدة للقلب وكذلك تم أخذ الأجز اء المتبقية من عضلة القلب من جميع المجموعات وتجهيز ها للفحص بالمجهرين الضوئي والإلكتروني. النتائج: أظهرت هذه الدر اسة أن عقار الدوكس أدى إلى تغير ات نسيجية تمثلت فى عدم انتظام الألياف العضلية للقلب مع ظهور فجوات بهاو تدهور في الميتوكوندريا. كذللك لوحظ اتساع و احتقان في الأوعية الدموية. أيضا، لوحظ انخفاض معنوي في المستوى الكلي لقدرة الأكسدة للقلب والبروتين الدهني عالي الكثافة في الدم مع زيادة مستويات نازعة هيدروجين اللاكتات و الكرياتين كيناز و الدهون الثناثية و الكوليسترول الكلي في الدم. لوحظ أيضًا أن استخدام ثيتامين هـ المسبق و المصاحب لعقار الدوكس قد أدى إلى تحسن ملحوظ في النتائج النسيجية و المعملية. الخلاصة: نستنتج من هذه الدر اسة أن قيتامين هـ يخفف الأضر ار النسيجية والبيوكيميائية التي يسببها عقار الدوكس على 